\title{
A synthesis of patterns of environmental mercury inputs, exposure and effects in New York State
}

\author{
D. C. Evers $\mathbb{D}^{1}$ - A. K. Sauer ${ }^{1,2}$ - D. A. Burns ${ }^{3}$ - N. S. Fisher ${ }^{4}$ - D. C. Bertok ${ }^{5} \cdot$ E. M. Adams ${ }^{1}$ - M. E. H. Burton ${ }^{1}$. \\ C. T. Driscoll ${ }^{2}$
}

Accepted: 14 October 2020 / Published online: 10 November 2020

(C) The Author(s) 2020

\begin{abstract}
Mercury ( $\mathrm{Hg}$ ) pollution is an environmental problem that adversely affects human and ecosystem health at local, regional, and global scales-including within New York State. More than two-thirds of the $\mathrm{Hg}$ currently released to the environment originates, either directly or indirectly, from human activities. Since the early 1800s, global atmospheric Hg concentrations have increased by three- to eight-fold over natural levels. In the U.S., atmospheric emissions and point-source releases to waterways increased following industrialization into the mid-1980s. Since then, water discharges have largely been curtailed. As a result, $\mathrm{Hg}$ emissions, atmospheric concentrations, and deposition over the past few decades have declined across the eastern U.S. Despite these decreases, Hg pollution persists. To inform policy efforts and to advance public understanding, the New York State Energy Research and Development Authority (NYSERDA) sponsored a scientific synthesis of information on $\mathrm{Hg}$ in New York State. This effort includes 23 papers focused on $\mathrm{Hg}$ in atmospheric deposition, water, fish, and wildlife published in Ecotoxicology. New York State experiences Hg contamination largely due to atmospheric deposition. Some landscapes are inherently sensitive to $\mathrm{Hg}$ inputs driven by the transport of inorganic $\mathrm{Hg}$ to zones of methylation, the conversion of inorganic $\mathrm{Hg}$ to methylmercury, and the bioaccumulation and biomagnification along food webs. Mercury concentrations exceed human and ecological risk thresholds in many areas of New York State, particularly the Adirondacks, Catskills, and parts of Long Island. Mercury concentrations in some biota have declined in the Eastern Great Lakes Lowlands and the Northeastern Highlands over the last four decades, concurrent with decreases in water releases and air emissions from regional and U.S. sources. However, widespread changes have not occurred in other ecoregions of New York State. While the timing and magnitude of the response of $\mathrm{Hg}$ levels in biota varies, policies expected to further diminish $\mathrm{Hg}$ emissions should continue to decrease $\mathrm{Hg}$ concentrations in food webs, yielding benefits to the fish, wildlife, and people of New York State. Anticipated improvements in the $\mathrm{Hg}$ status of aquatic ecosystems are likely to be greatest for inland surface waters and should be roughly proportional to declines in atmospheric $\mathrm{Hg}$ deposition. Efforts that advance recovery from $\mathrm{Hg}$ pollution in recent years have yielded significant progress, but $\mathrm{Hg}$ remains a pollutant of concern. Indeed, due to this extensive compilation of $\mathrm{Hg}$ observations in biota, it appears that the extent and intensity of the contamination on the New York landscape and waterscape is greater than previously recognized. Understanding the extent of $\mathrm{Hg}$ contamination and recovery following decreases in atmospheric $\mathrm{Hg}$ deposition will require further study, underscoring the need to continue existing monitoring efforts.
\end{abstract}

Keywords Mercury $\cdot$ Air $\cdot$ Fish $\cdot$ Bird $\cdot$ New York

$\triangle$ D. C. Evers

david.evers@briloon.org

1 Biodiversity Research Institute, 276 Canco Road, Portland, ME 04103, USA

2 Syracuse University, Syracuse, NY 13244, USA
3 U.S. Geological Survey, Troy, NY 12180, USA

4 School of Marine and Atmospheric Sciences, Stony Brook University, Stony Brook, NY 11794, USA

5 New York State Energy Research and Development Authority, Albany, NY 12203, USA 


\section{Introduction}

Mercury pollution is an environmental problem with local, regional, and global dimensions that adversely affects human and ecosystem health-including that in New York State, USA. Mercury $(\mathrm{Hg})$ is a naturally occurring element that is emitted from volcanoes and released by natural processes such as soil weathering (Driscoll et al. 2013). However, more than two-thirds of the $\mathrm{Hg}$ currently released to the environment globally originates, either directly or indirectly, from human activities (Amos et al. 2013). For more than 200 years, $\mathrm{Hg}$ has been released into the atmosphere and waterways in New York State by human activities, including emissions from fossil fuel combustion, waste incineration, metal smelting, and chlorine production, and discharges to surface waters from domestic and industrial wastewater. Since the early 1800 s, global releases have increased atmospheric $\mathrm{Hg}$ concentrations by three- to eight-fold above natural levels (Streets et al. 2017; UN Environment 2019).

Mercury has long been recognized as an important environmental problem in New York State (Bloomfield et al. 1980). Factors that contribute to this condition include: the location downwind of the many coal-fired power plants in the Ohio River Valley; extensive forested lands particularly in the Adirondacks and Catskills that enhance deposition; an abundance of wetlands that facilitate methylation; and numerous streams, rivers, lakes, and estuaries with extensive fish populations and other wildlife that are exposed to methylmercury $(\mathrm{MeHg})$ through trophic transfer (Driscoll et al. 2007). As a result, there are many Hg-related fish consumption advisories for specific inland freshwaters, the two Great Lakes (Erie, Ontario), and coastal areas of New York State, as well as blanket advisories for the Adirondacks and Catskills (https://www.health.ny.gov/environmental/ outdoors/fish/health_advisories/). Despite these challenges, efforts are underway to curb $\mathrm{Hg}$ pollution.

Under the Great Lakes Water Quality Agreement, Environment Canada and the U.S. Environmental Protection Agency (US EPA) signed the Great Lakes Binational Toxics Strategy in 1997 calling for virtual elimination of $\mathrm{Hg}$ emissions originating from human sources in the Great Lakes region (US EPA 1997). The Great Lakes Regional Collaboration built on this effort and in 2010 produced the Great Lakes Mercury Emission Reduction Strategy with recommendations for decreasing emissions from the largest remaining sources in the basin. The Mercury Air Toxics Standards (MATS) rule went into effect in 2015 with a goal of achieving $91 \%$ reductions in $\mathrm{Hg}$ emissions from electric utilities (https://www.epa.gov/mats). At the global scale, the Minamata Convention on Mercury entered into force in August 2017, which includes the United States as a ratified Party for this international treaty (Evers et al. 2016).
To advance scientific and public understanding and to inform policy efforts, the New York State Energy Research and Development Authority (NYSERDA) sponsored a scientific synthesis on $\mathrm{Hg}$ in atmospheric deposition, water, invertebrates, fish, and wildlife in New York State. The result of this scientific collaboration is a series of 23 papers published in Ecotoxicology (Table 1). The findings from these studies are summarized here in the context of an extensive statewide database of $\mathrm{Hg}$ concentrations in atmospheric deposition, surface waters, and in a broad array of biota including fish, birds, invertebrates, and others that were compiled as part of the scientific synthesis. The database is presented in summarized form and results from the 23 papers are integrated into this summary article as we answer a series of questions about $\mathrm{Hg}$ in New York State including the concentrations that occur and associated risks, spatial and temporal patterns, and policies that are addressing exposure risks.

\section{Study area}

The USEPA has identified 104 ecoregions across the U.S. In New York, USEPA Level III Ecoregions divide the state into similar lands based on patterns in the mosaic of biotic, abiotic, aquatic, and terrestrial ecosystem components (Fig. 1). These ecoregions provide a spatial framework to evaluate $\mathrm{Hg}$ exposure patterns of fish and wildlife that are adapted to these different environments (Fig. 2).

\section{Methods}

\section{Sampling and measurement units}

Observations of $\mathrm{Hg}$ concentrations in abiotic media (air, water) and biotic samples (invertebrates, fish, amphibians, reptiles, birds, and mammals) from New York State are available from 1969 through 2017; the total sample size within the New York State $\mathrm{Hg}$ database described in this paper was over 70,000 observations of $\mathrm{Hg}$ concentrations (including over 47,000 from biota-Table 2). These data comprise the "NYSERDA Synthesis of Environmental Mercury Loads in New York State (1969-2017)" (NYSMD), which is available at Open NY (see Acknowledgments section for URL). Mercury biota data were standardized for each major taxonomic group to a common tissue type (Table 2). For most species, total mercury ( $\mathrm{THg}$ ) was measured and predominantly occurs as $\mathrm{MeHg}$, but in species where $\mathrm{MeHg}$ is a smaller fraction of $\mathrm{THg}, \mathrm{MeHg}$ concentrations were directly measured and are identified within this paper when relevant. Mercury in biotic samples is generally reported in parts per million (ppm) of wet weight (ww). 


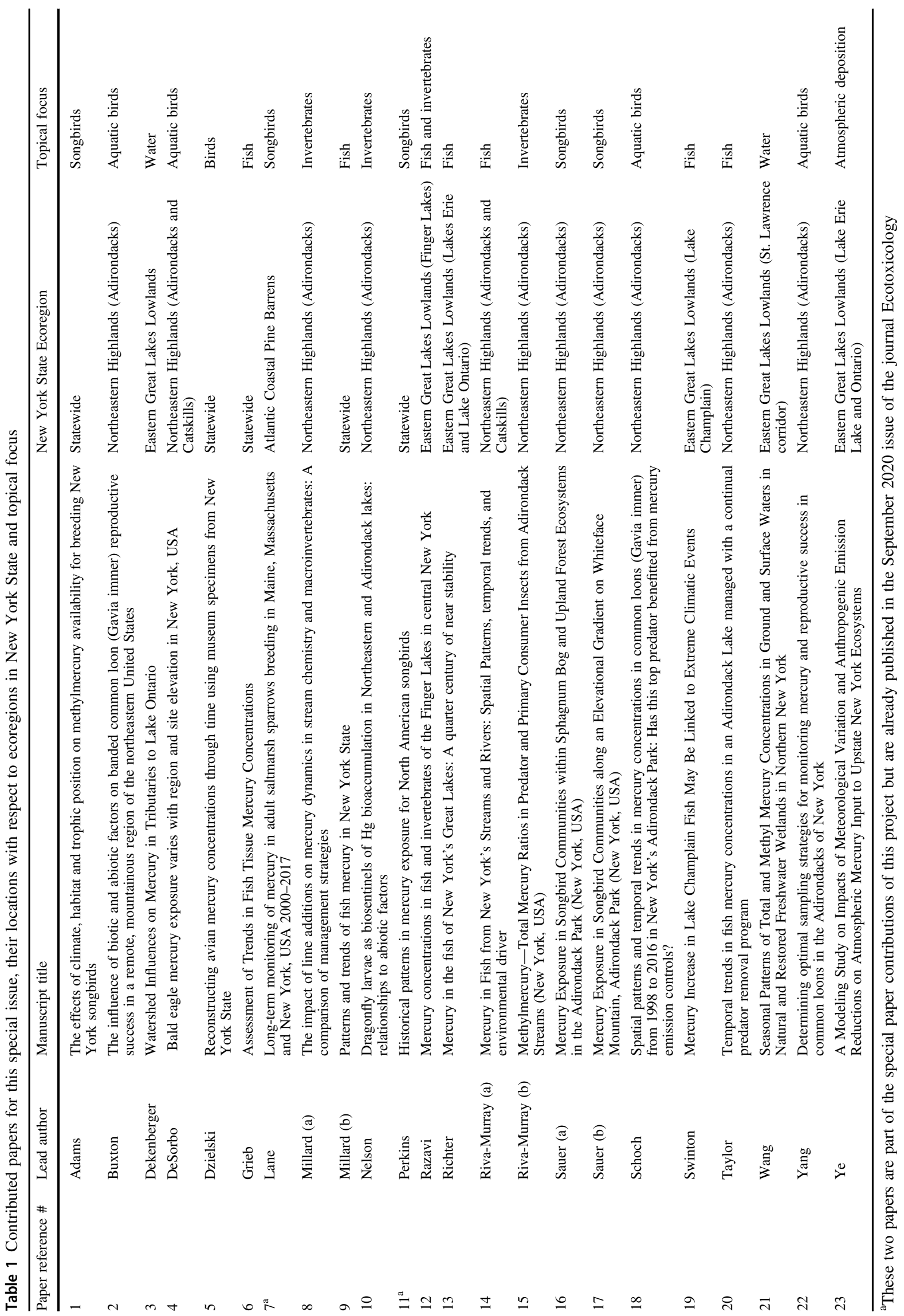




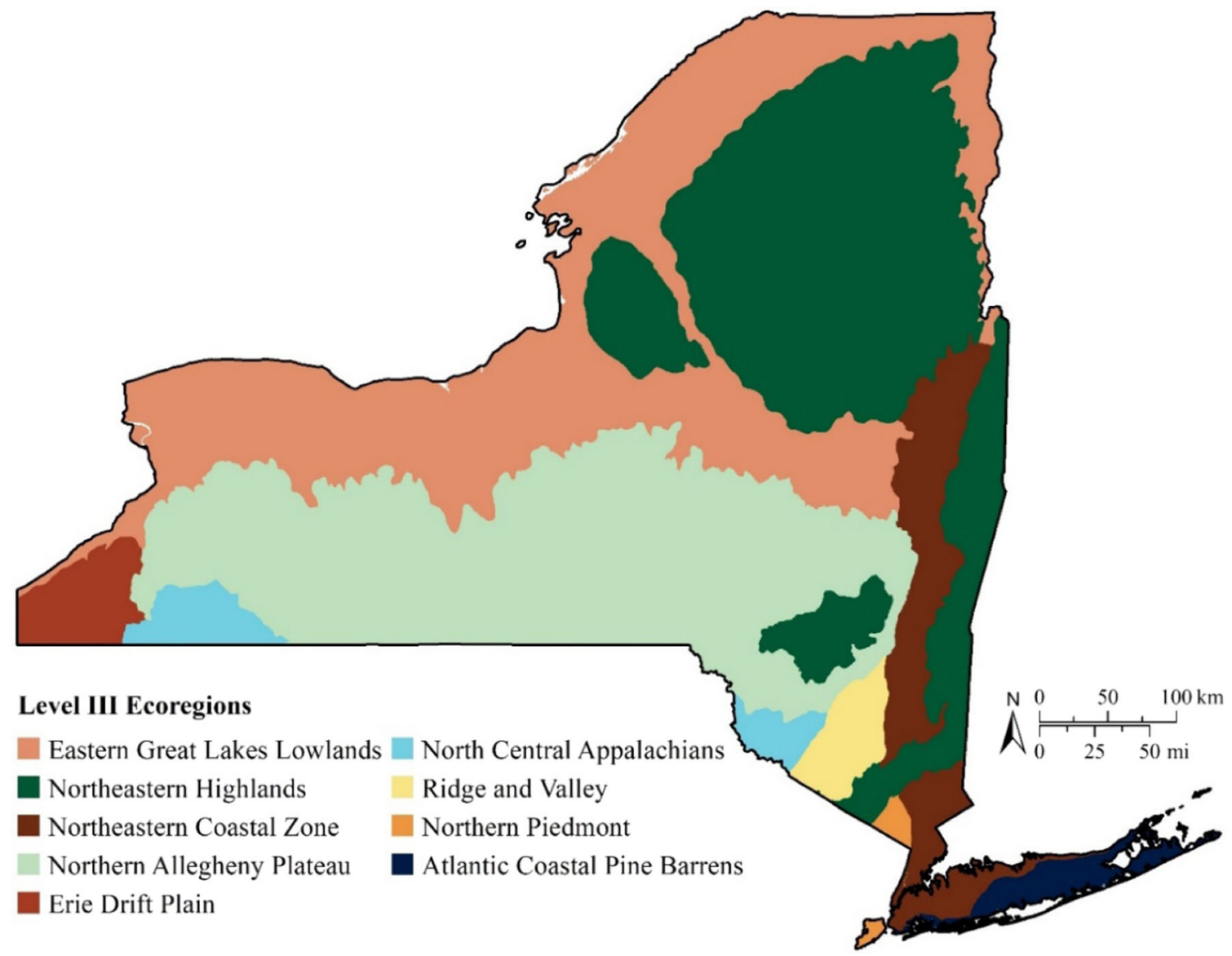

Fig. 1 Ecoregions across New York State, United States (Data obtained at: https://www.epa.gov/eco-research/level-iii-and-iv-ecoregions-continentalunited-states)

\section{Spatial grid system}

To examine $\mathrm{Hg}$ patterns in biota (i.e., fish, birds) across New York, the state was divided into $1 / 8$ by $1 / 8$ degree grid cells, each of which represents approximately 250 square kilometers. The number in each grid cell in Fig. 3 depicts the number of wildlife species sampled for $\mathrm{Hg}$. This approach was used in past assessments of effects of $\mathrm{Hg}$ loads including biota for the Great Lakes (Evers et al. 2011).

The data from the NYSMD were overlaid across the spatial grid system after standardization of $\mathrm{Hg}$ data (Fig. 3). All $\mathrm{THg}$ observations were first standardized to a representative tissue type for each taxonomic group. When relevant, bird observations were converted to blood THg (ppm, ww) (Eagles-Smith et al. 2009; Evers et al. 2011). All fish $\mathrm{THg}$ data were standardized to whole fish THg (ppm, ww) and were length-standardized to control for variation attributable to size and age using a species-specific general linear mixed model (Buck et al. 2019).

\section{Spatial analyses}

A spatial analyses was conducted to explore variation of fish $\mathrm{Hg}$ concentrations across the state in the context of human and wildlife health risk, with a focus on the landscape characteristics that affect spatial patterns. Two subsets of the NYSMD were created for the spatial analysis. The first included all fish data, while the second subset selected for game fish. These two datasets were then independently analyzed with a general linear mixed model fit in a Bayesian framework using packages rstan and rstanarm (Carpenter et al. 2017; Goodrich et al. 2018; Stan Development Team 2018) within the $R$ statistical modeling environment (v 3.5.1; R Core Team 2018). Foraging guild and tissue type were fixed effects, while sampling year and species were random effects nested within grid cell as a spatial covariate. The model predicted mean $\mathrm{THg}$ concentrations for all fish at an omnivore or higher trophic level for each grid cell where a fish was sampled and were then mapped across New York State. See Adams et al. (2020) for further information on data compilation, standardization, and model development. 


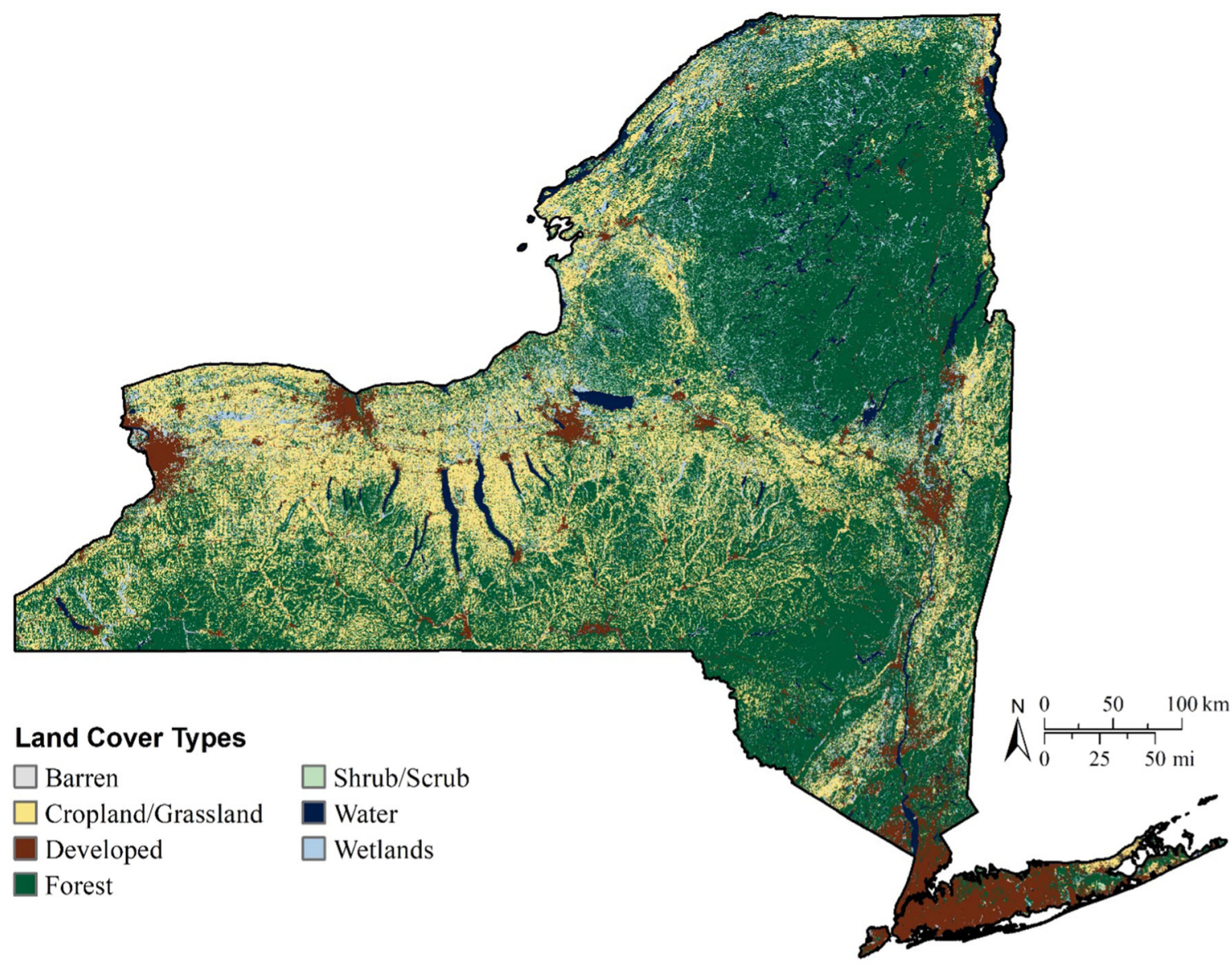

Fig. 2 Land cover types of New York State. The state has more than 7600 freshwater lakes, ponds, and reservoirs, as well as portions of Lake Erie and Lake Ontario and over $112,000 \mathrm{~km}$ of rivers and streams. After the Great Lakes, New York's largest lakes include Champlain, Oneida, Seneca, and Cayuga Lakes. Seneca and Cayuga Lakes are part of a series of long, narrow lakes known as the Finger

To better understand the implications of these results for human health, the fish $\mathrm{THg}$ concentrations are presented in relation to effect level thresholds published jointly by the US Food and Drug Administration and US EPA (FDA/EPA 2019; see Table 3 for consumption guidelines).

Additionally, landscape scale variables play an important role in $\mathrm{Hg}$ availability to biota. Mercury concentrations in fish are driven in part by the $\mathrm{Hg}$ inputs (e.g., atmospheric deposition), methylation rates, and trophic level. A portion of the atmospherically deposited $\mathrm{Hg}$ is converted to its bioavailable form, MeHg. Landscape characteristics can amplify this conversion process to contribute to the spatial heterogeneity of $\mathrm{Hg}$ across the landscape. A spatial analysis of Land Use and Land Cover (LULC) data for New York State was conducted to highlight these relationships. The percent cover of forest and agriculture were extracted, for each grid cell, from the National Land Cover Database (NLCD) and, where grid cells overlapped spatially with
Lakes located in central New York. The State's largest rivers include the St. Lawrence, Susquehanna, Allegheny, Hudson, and Delaware Rivers (Data obtained at: https://www.usgs.gov/centers/eros/science/ national-land-cover-database?qt-science_center_objects $=0 \#$ qtscience_center_objects)

Canada, the Land Cover of Canada database (Latifovic et al. 2017; Yang et al. 2018). A simple linear model was then constructed to examine the relationship between game fish Hg and LULC (forest and agriculture, respectively) by grid cell.

\section{Temporal analyses}

Temporal analyses were conducted to assess changes in $\mathrm{Hg}$ concentrations for 15 well-sampled ( $>10$ total years of sampling, $>400$ total samples) indicator species (11 fish and four birds) by USEPA Level III Ecoregions in New York State. This dataset was also analyzed using a general linear mixed model with the same framework as the spatial analysis. The temporal model used tissue type as a fixed effect, while the nested effect of ecoregion, species, and year were random effects. The output of this model predicted a species-specific mean $\mathrm{Hg}$ concentration 
Table 2 Biota sampled in New York State from 1969 to 2017 and standardized tissue type that were used for 20 papers within this special issue reporting biological data

\begin{tabular}{|c|c|c|c|}
\hline Taxa & Tissue & $\mathrm{Hg}$ type/unit & Sample size \\
\hline $\begin{array}{l}\text { Mollusks and other } \\
\text { invertebrates }\end{array}$ & $\begin{array}{l}\text { Whole body/ } \\
\text { muscle }\end{array}$ & $\begin{array}{l}\mathrm{THg}, \mathrm{MeHg} / \\
\text { ppm, ww }\end{array}$ & 2733 \\
\hline Fish & $\begin{array}{l}\text { Whole body/ } \\
\text { muscle }\end{array}$ & $\mathrm{THg} / \mathrm{ppm}$, ww & 33,502 \\
\hline Amphibians & Muscle & $\mathrm{THg} / \mathrm{ppm}$, ww & 109 \\
\hline Reptiles & Scute & $\mathrm{THg} / \mathrm{ppm}, \mathrm{fw}$ & 96 \\
\hline Bird: invertivores & Blood & $\mathrm{THg} / \mathrm{ppm}$, ww & 8101 \\
\hline $\begin{array}{l}\text { Bird: piscivores/ } \\
\text { carnivores }\end{array}$ & Blood & $\mathrm{THg} / \mathrm{ppm}$, ww & 1650 \\
\hline Mammal: invertivores & Fur & $\mathrm{THg} / \mathrm{ppm}, \mathrm{fw}$ & 486 \\
\hline Mammal: piscivores & Fur & $\mathrm{THg} / \mathrm{ppm}, \mathrm{fw}$ & 511 \\
\hline Total sampled & & & 47,188 \\
\hline
\end{tabular}

The abbreviation $f w$ refers to fresh weight without any drying of tissue prior to analysis (usually used for keratin-based tissues), whereas $w w$ refers to analyses of tissues with a significant moisture content. Dry weight $(d w)$, although not used here, refers to analyses of tissues after extracting all moisture annually for each ecoregion, year combination sampled for that respective species (while controlling for grid-cell level spatial variation). These predicted values were then input into a series of linear models to examine speciesspecific trends in $\mathrm{Hg}$ concentrations through time for each ecoregion, species combination with more than 2 years of sampling. See Adams et al. (2020) for further information on data compilation, standardization, and model development.

\section{Results and discussion}

Measurements of environmental $\mathrm{Hg}$ concentrations and fluxes improve understanding of $\mathrm{Hg}$ dynamics and effects in the environment and help parameterize models that simulate and project fate and exposure of $\mathrm{Hg}$. Through a collaborative effort, this special issue of Ecotoxicology includes 23 papers representing a wide variety of $\mathrm{Hg}$ studies across New York State including atmospheric deposition (one paper), surface waters (two papers),

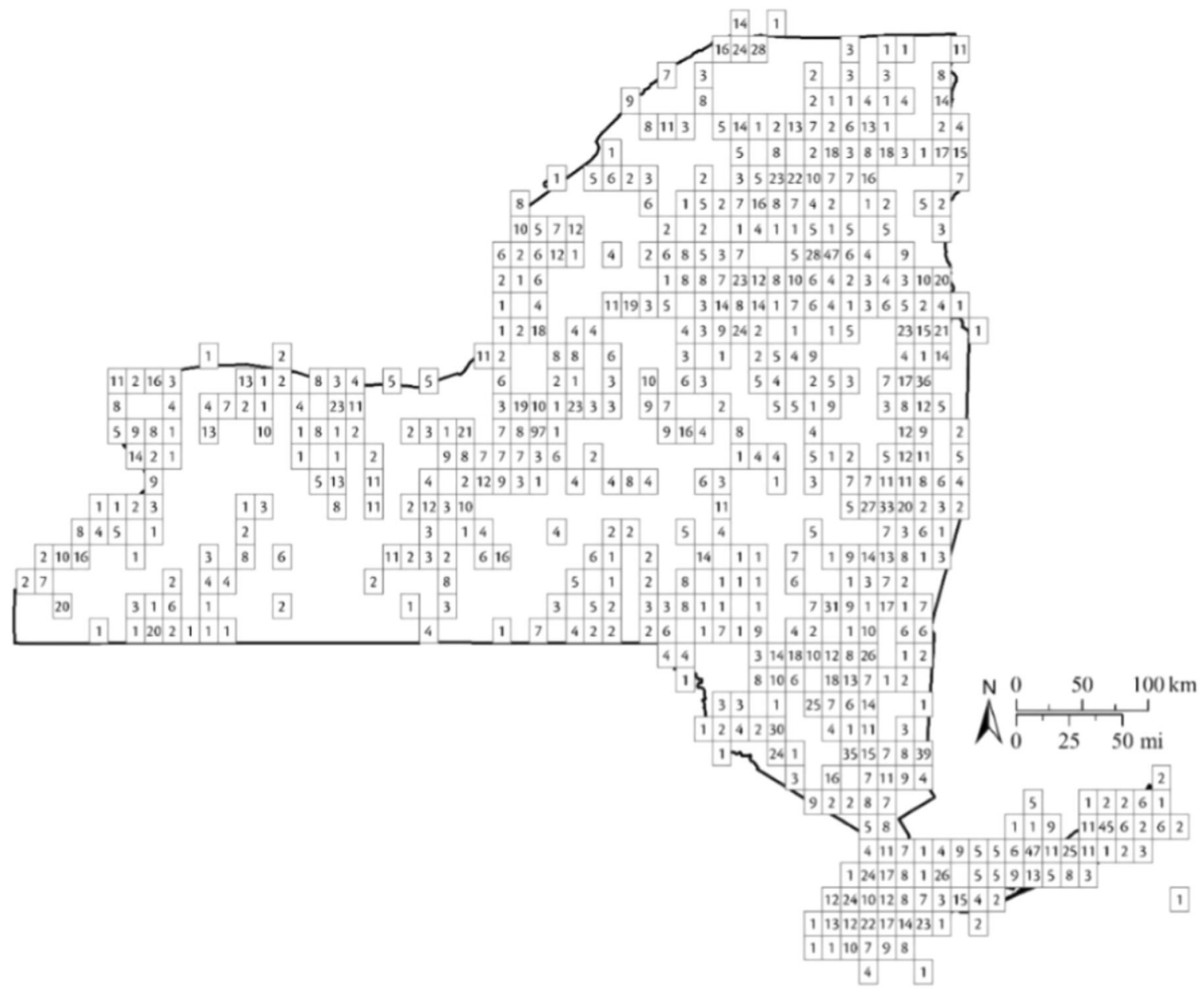

Fig. 3 The spatial grid system (1/8 by 1/8 degree grid cells used for defining spatial gradients of biotic Hg concentrations in New York State. The number in each cell represents the number of species of fish and wildlife with $\mathrm{Hg}$ observations in the area 
Table 3 Fish $\mathrm{Hg}$ concentrations and meal frequency guidelines ${ }^{\mathrm{a}}$

\begin{tabular}{|c|c|c|}
\hline Guideline or criterion by agency/entity & $\begin{array}{l}\text { Mercury in fish } \\
\text { (ppm, ww) }\end{array}$ & $\begin{array}{l}\text { Fish consumption } \\
\text { guideline }\end{array}$ \\
\hline \multirow[t]{4}{*}{ New York State Department of Health } & $\begin{array}{l}<1.0 \text { : general and } \\
\text { sensitive population }\end{array}$ & Four meals per month \\
\hline & $\begin{array}{l}\geq 1.0-<2.0: \text { sensitive } \\
\text { population }\end{array}$ & No consumption \\
\hline & $\begin{array}{l}\geq 1.0-<2.0 \text { : general } \\
\text { population }\end{array}$ & One meal per month \\
\hline & $\begin{array}{l}>2.0 \text { : general and } \\
\text { sensitive populations }\end{array}$ & No consumption \\
\hline \multirow{5}{*}{$\begin{array}{l}\text { Great Lakes Consortium for Fish Consumption } \\
\text { Advisories (for both sensitive and general } \\
\text { populations) }{ }^{\mathrm{b}}\end{array}$} & $0.0-\leq 0.05$ & Unrestricted \\
\hline & $0.05-0.10$ & Two meals per week \\
\hline & $0.11-0.21$ & One meal per week \\
\hline & $0.22-0.95$ & One meal per month \\
\hline & $>0.95$ & No consumption \\
\hline \multirow{4}{*}{$\begin{array}{l}\text { USEPA—Food and Drug Administration Fish } \\
\text { Advice: technical information }{ }^{c}\end{array}$} & $\leq 0.15$ & Three meals per week \\
\hline & $0.16-0.22$ & Two meals per week \\
\hline & $0.23-0.46$ & One meal per week \\
\hline & $>0.46$ & No consumption \\
\hline
\end{tabular}

${ }^{a}$ Mercury concentrations are interpreted in the context of the number of fish meals that could be consumed to stay within the USEPA health-based reference dose for MeHg (USEPA 2001)

${ }^{\mathrm{b}}$ GLRC 2010

cUSEPA; https://www.epa.gov/fish-tech/epa-fda-fish-advice-technical-information\# invertebrates (three papers), fish (seven papers) and birds (ten papers) (Table 1). These papers collectively characterize environmental $\mathrm{Hg}$ deposition and concentrations in ecosystems of New York State, evaluate patterns of methylation, determine bioaccumulation and exposure in aquatic and terrestrial food webs, and address temporal trends of $\mathrm{Hg}$ in the context of changes in emissions and atmospheric deposition using various biota. This work also places $\mathrm{Hg}$ contamination in New York State in context with other areas of the U.S (Grieb et al. 2020; Olson et al. 2020). Integrating the findings from these papers provides a robust assessment of the impact of $\mathrm{Hg}$ on ecosystems of New York State, as well as a broader scientific basis for policymakers and natural resource managers to make informed decisions regarding future air regulations and fish consumption advisories.

Our findings about the extent and effects of $\mathrm{Hg}$ pollution in New York State are described in the context of three policy-relevant questions: (1) What are the sources of $\mathrm{Hg}$ inputs to New York State and how do these inputs vary over space and time?; (2) What risks does mercury pollution pose to humans in New York State?; and (3) What are the spatial and temporal patterns of $\mathrm{Hg}$ in biota in New York State and to what extent do these reflect sensitivity to $\mathrm{Hg}$ inputs and changes in those inputs? Specific science-policy connections are addressed at the end of this paper.

\section{What are the sources of mercury inputs to New York State and how do these inputs vary over space and time?}

\section{Mercury emission sources that affect New York State}

Initial regulatory efforts in the 1970s focused on large industrial sources of $\mathrm{Hg}$, such as chlor-alkali plants. These point sources discharged $\mathrm{Hg}$ directly or indirectly into the Great Lakes and their tributaries. Today, many of these sources have been reduced or eliminated, which has led to a partial recovery from point-source $\mathrm{Hg}$ pollution (Evers and Clair 2005; Cain et al. 2011; Drevnick et al. 2012; Todorova et al. 2014). Atmospheric emissions and deposition are currently the largest source of $\mathrm{Hg}$ to New York State. Stationary sources (e.g., fossil fuel burning plants and waste incinerators) emit $\mathrm{Hg}$ into the atmosphere as gaseous elemental $\mathrm{Hg}$, gaseous oxidized $\mathrm{Hg}$, or particulate bound $\mathrm{Hg}$. Gaseous elemental $\mathrm{Hg}$ can be transported long distances (atmospheric residence time $\sim 0.5-1$ yr), while gaseous oxidized $\mathrm{Hg}$ and particulate bound $\mathrm{Hg}$ tend to be deposited near the source (hours to days). For this reason, $\mathrm{Hg}$ deposition to New York State can originate from local, regional, national, or global sources.

Controls on $\mathrm{Hg}$ emissions in the US were first initiated by designation of $\mathrm{Hg}$ as a hazardous air pollutant through the 1990 Amendments of the Clean Air Act (CAA). The US 


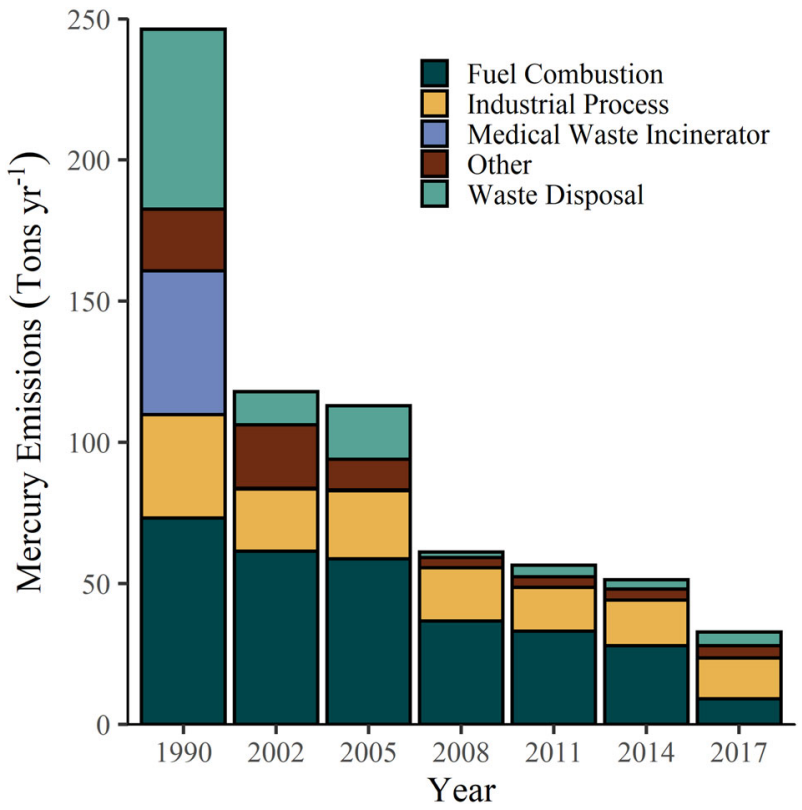

Fig. 4 US EPA National Emissions Inventory (NEI) estimates of $\mathrm{Hg}$ emitted to the air by major sources in the United States from 1990 to 2017. Coal-fired power plants remain the largest source of $\mathrm{Hg}$ emissions in the US (USEPA 2020)

EPA was required to list and set emissions standards which later resulted in a finding that it was appropriate and necessary to regulate $\mathrm{Hg}$ emissions from coal- and oil-fired power plants and other sources such as incinerators (Milford and Pienciak 2009). This began a regulatory process which has led to a more than four-fold decline in U.S. anthropogenic $\mathrm{Hg}$ emissions between 1990 and 2017 (Olson et al. 2020). During 1990 to 2005, the largest decreases in $\mathrm{Hg}$ emissions were from hospital and municipal incinerators (96-99\% decrease) and chlor-alkali facilities (97\% decrease; Schmeltz et al. 2011). Mercury emissions from electric utilities have declined since the 1990s due to a variety of state and federal regulations, many of which affected emissions indirectly as co-benefits of controlling other pollutants such as sulfur dioxide and nitrogen oxides (Milford and Pienciak 2009; Schmeltz et al. 2011; Zhang et al. 2016) and in recent years following the implementation of the MATS rule. The average rate of decline of $\mathrm{Hg}$ emissions from electric utilities was -7.4 percent per year during 1996 to 2017 (Olson et al. 2020). In the U.S., approximately 52 tons of $\mathrm{Hg}$ were annually emitted from anthropogenic sources in 2014 (Bourtsalas and Themelis 2019), decreasing to 33 tons in 2017. Emissions of $\mathrm{Hg}$ from coal-fired power plants have decreased to the point that they are no longer the largest source of anthropogenic atmospheric $\mathrm{Hg}$ emissions in the U.S., being replaced by industrial processes (Fig. 4). There are major and minor sources of anthropogenic Hg emission sources across New York State, the largest $\mathrm{Hg}$ emission source is "other

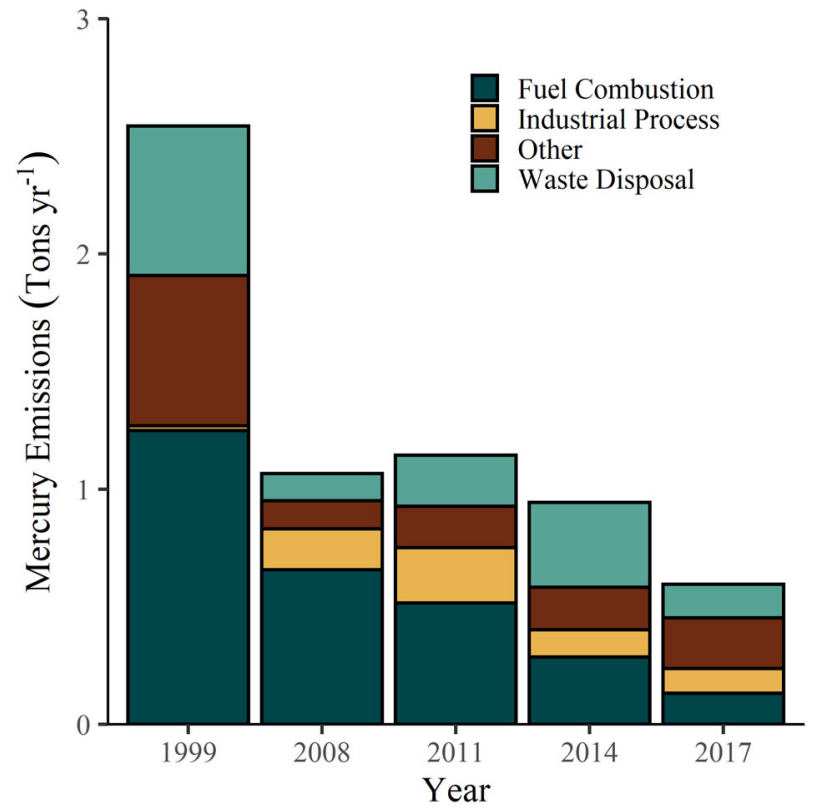

Fig. 5 US EPA NEI estimates of $\mathrm{Hg}$ emitted to the air by major source in New York State from 1999 to 2017 (USEPA 2020)

categories" which include nonpoint emissions and point source emissions associated with various industries (Fig. 5). In contrast to declines in New York State and the U.S., inventories suggest that global anthropogenic $\mathrm{Hg}$ emissions have increased in recent years (Streets et al. 2019; UN Environment 2019). Asia continues to be a dominant contributor to $\mathrm{Hg}$ emissions globally, due largely to expanding energy production from coal-fired power plants and gold mining.

Source attribution of $\mathrm{Hg}$ has been conducted for New York State and the Northeast. Lin et al. (2012) conducted source apportionment of $\mathrm{Hg}$ emissions for the contiguous $\mathrm{U}$. S. using the Community Multiscale Air Quality (CMAQ) model. In New York and New England, relatively high contributions of $\mathrm{Hg}$ were derived from electrical generating units and waste incineration. Sources outside the U.S. also contributed to Hg deposition in New York and New England but the fractions were smaller than in many other regions of the U.S. Choi et al. (2008) conducted source contribution analysis for forms of atmospheric $\mathrm{Hg}$ in the Adirondacks observing that Pennsylvania, West Virginia, Ohio, Kentucky, Texas, Indiana, and Missouri were important contributing areas.

\section{Spatial and temporal patterns in atmospheric $\mathrm{Hg}$ concentrations and deposition}

Ye et al. (2020) modeled Hg deposition across New York State, using CMAQ with state-of-the-science air chemistry algorithms. They examined the contribution of local emissions and the role of environmental variables to spatial 
(a) Dry Deposition $\left(\mu \mathrm{g} / \mathrm{m}^{2}\right)$
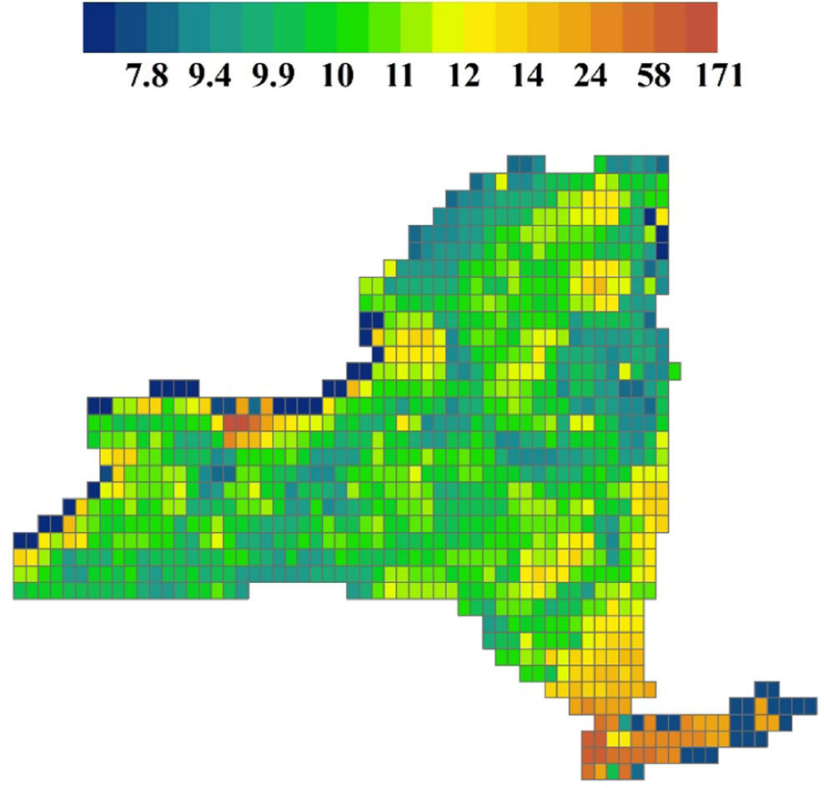

Fig. 6 Simulated spatial patterns of dry and wet $\mathrm{Hg}$ deposition across New York State based on Ye et al. (2020) at a $1 / 8$ by $1 / 8$ degree grid scale. Patterns of (a) dry and (b) wet $\mathrm{Hg}$ deposition vary considerably

patterns of $\mathrm{Hg}$ deposition (Fig. 6). Meteorological conditions and forest canopy characteristics were the most important factors affecting spatial patterns in $\mathrm{Hg}$ wet and dry deposition, respectively.

Dry deposition: Local, anthropogenic $\mathrm{Hg}$ emissions sources increase deposition rates over water and land within $50 \mathrm{~km}$ of the point source. For example, emission sources near Rochester, in Manhattan, and on Long Island contribute to elevated dry $\mathrm{Hg}$ deposition in those areas (Fig. 6a). Environmental factors such as wind speed and heat flux (changes in temperature across the surface of water and land) drive spatial patterns of deposition in aquatic habitats, while increased canopy cover associated with forested lands lead to greater deposition in terrestrial landscapes.

Wet deposition: The amount of precipitation is an important driver of spatial variation in wet $\mathrm{Hg}$ deposition to aquatic and terrestrial habitats. Higher levels of precipitation downwind of Lake Erie and Lake Ontario lead to increased $\mathrm{Hg}$ deposition in the central and western regions of the state (Fig. 6b).

In the U.S., concentrations of atmospheric $\mathrm{Hg}$ species are monitored by the Atmospheric Mercury Network (AMNet; http://nadp.slh.wisc.edu/amnet/). In New York State, there are three AMNet sites of the National Atmospheric Deposition Program. Olson et al. (2020) examined temporal trends in atmospheric $\mathrm{Hg}$ species generally finding decreases in concentrations of gaseous elemental $\mathrm{Hg}$ (7a) and gaseous oxidized $\mathrm{Hg}(7 \mathrm{~b})$ in the Northeast from 2008 to

\section{(b) Wet Deposition $\left(\mu \mathrm{g} / \mathrm{m}^{2}\right)$}
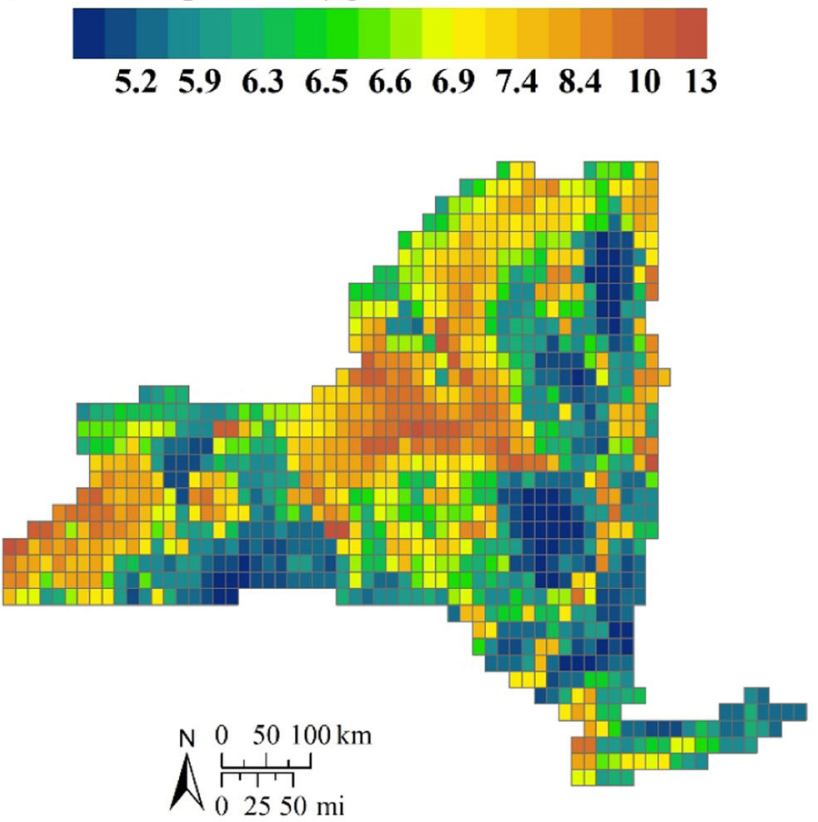

across the state due to emissions point sources, precipitation, wind speed, heat flux, and land cover. The z-axes for dry and wet deposition are shown on different scales

2017, which are consistent with regional and national decreases in emissions. Trends for particulate bound $\mathrm{Hg}$ are more varied with some sites in New York State showing increases in concentrations (7c), which may be caused by wood burning in winter (Zhou et al. 2017) (Fig. 7).

Trends in wet $\mathrm{Hg}$ deposition are monitored by the Mercury Deposition Network (MDN; http://nadp.slh.wisc. edu/mdn), of the National Atmospheric Deposition Program, including six sites in New York State. Olson et al. (2020) evaluated long-term temporal trends in wet $\mathrm{Hg}$ deposition during 1996 to 2017. They found generally consistent decreasing trends in annual volume-weighted concentrations for stations in the eastern U.S., including all of those in New York State (Fig. 8a) which is generally consistent with decreases in U.S. emissions. Trends in annual wet $\mathrm{Hg}$ deposition are less than those of concentrations, although many sites in the Northeast show significant decreasing trends (Fig. 8b). This diminished trend is due to considerable year-to-year variability in precipitation quantity and a general pattern of increasing precipitation quantity in the Northeast (Fig. 8c).

Landscape factors have been shown to exert important controls on $\mathrm{Hg}$ deposition. In particular, the forest canopy mediates land-atmosphere exchange of $\mathrm{Hg}$. Elemental $\mathrm{Hg}$ enters the stomata of leaves and is later deposited to soil as litterfall. Ionic $\mathrm{Hg}$ can be adsorbed to the surface of leaves and needles and washed off during subsequent rain events and deposited as throughfall. In New York State, studies 


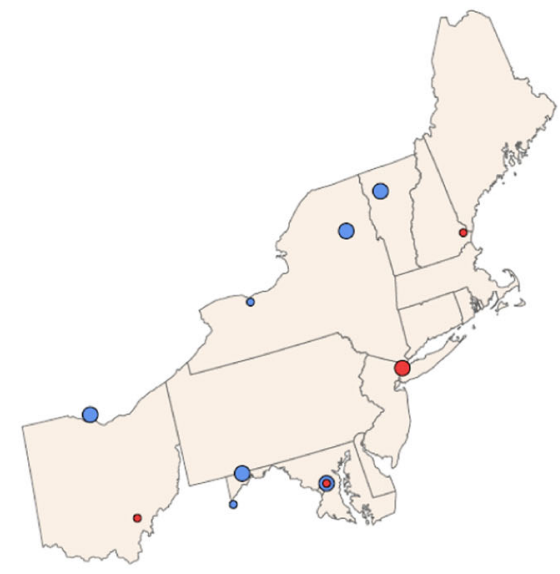

Fig. 7 Long-term temporal trends in concentrations of (a) gaseous elemental $\mathrm{Hg}$, (b) gaseous oxidized $\mathrm{Hg}$, and (c) particulate bound $\mathrm{Hg}$ for the northeastern U.S. A blue symbol indicates a decreasing trend
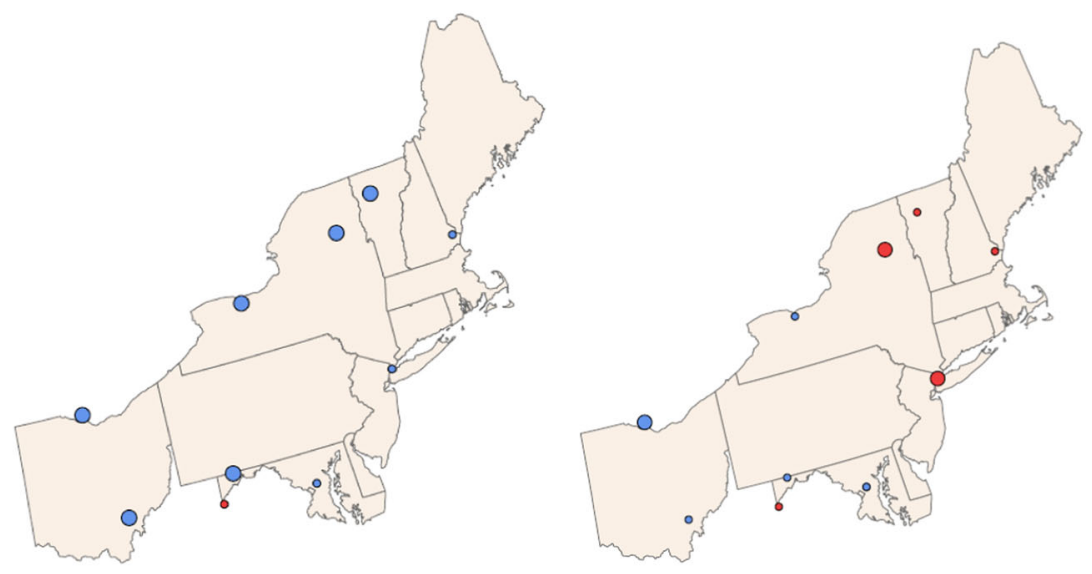

and a red symbol shows an increasing trend. Large symbols are indicative of a significant trend. Modified after Olson et al. (2020)

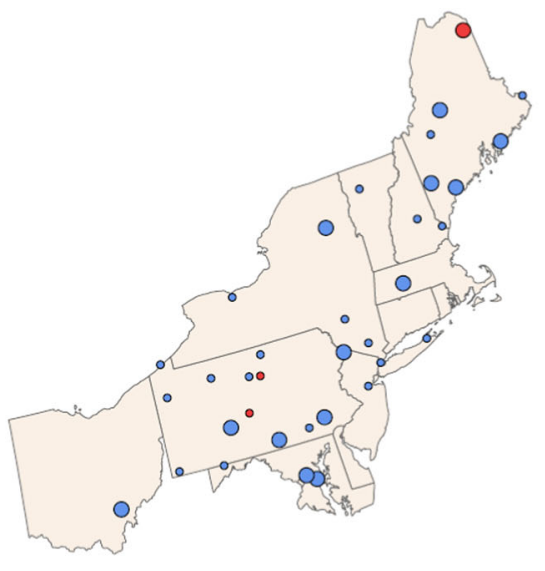

Fig. 8 Long-term trends in (a) annual volume-weighted concentrations of $\mathrm{Hg}$ in wet deposition, (b) annual wet $\mathrm{Hg}$ deposition and (c) annual precipitation quantity for the northeastern U.S. from the Mercury

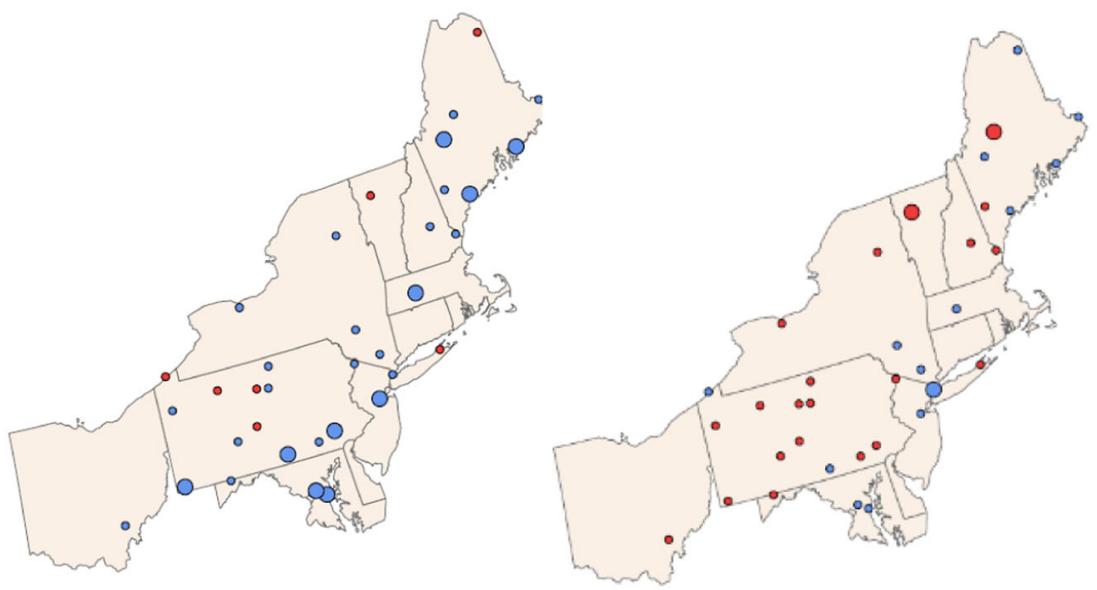

Deposition Network. A blue symbol indicates a decreasing trend and a red symbol shows an increasing trend. Large symbols are indicative of a significant trend. Modified after Olson et al. (2020) have shown that in hardwood stands litterfall is the largest pathway of $\mathrm{Hg}$ deposition to the forest floor (Blackwell et al. 2014). However, $\mathrm{Hg}$ deposition is typically greater in coniferous stands than in hardwoods because of the persistence of needles throughout the year and the high leaf area index of the coniferous canopy, and throughfall is the dominant pathway of $\mathrm{Hg}$ deposition (Blackwell et al. 2014). Finally, Hg deposition increases with elevation due to increases in precipitation quantity and shifts in vegetation (Blackwell and Driscoll 2015). At high elevations, cloud deposition can dominate atmospheric $\mathrm{Hg}$ input (Gerson et al. 2017). Soil and surface water $\mathrm{Hg}$ concentrations increase with elevation, likely reflecting increases in deposition (Blackwell and Driscoll 2015; Millard et al. 2020b).

\section{What risks to humans does mercury pollution pose in New York State?}

Fish are well-established bioindicators of environmental $\mathrm{Hg}$ loads and conditions that facilitate the transport, transformations and trophic transfer of $\mathrm{Hg}$. Fish data are used to understand long-term temporal trends in $\mathrm{Hg}$ (Millard et al. 2020b; Riva-Murray et al. 2020a; Richter and Skinner 2020; Swinton and Nierzwicki-Bauer 2020), evaluate human health concerns (Grieb et al. 2020), link to land management and water quality (Millard et al. 2020b; Razavi et al. 2020), and inform fisheries management (Taylor et al. 2020). Fish Hg data are also used to inform policy and management in New York State. 


\section{Mercury exposure-risks to humans}

Human populations most at risk of $\mathrm{MeHg}$ exposure include: (1) sensitive individuals (e.g., women of childbearing age, pregnant women, and children); and (2) people whose diets include large amounts of high trophiclevel fish (e.g., recreational anglers and subsistence fish consumers). The greatest risks to humans from dietary uptake of $\mathrm{MeHg}$ are observed with high consumption levels of upper trophic level species. For example, primary consumers (e.g., shellfish such as mussels) at trophic level 2 have relatively low $\mathrm{MeHg}$ concentrations and are considered safe for consumption. Secondary consumers (e.g., salmon, herring) are a trophic step higher, but are also healthy choices.

For tertiary or higher consumers, which include predatory fish (e.g., bass, walleye, bluefish), MeHg concentrations can be elevated to levels that raise human health concerns. The variability of concentrations in trophic level 4 fish can be related to size and species. Therefore, large trophic level 4 fish are the best bioindicators to assess potential exposure risk of $\mathrm{Hg}$ to humans. In coastal waters of New York State and nearby regions, large marine predatory fish such as tuna, swordfish and shark can have elevated $\mathrm{MeHg}$ concentrations, frequently exceeding the no consumption limits identified by the USEPA (i.e., 0.46 ppm, ww) and the Great Lakes Consortium (i.e., 0.95 ppm, ww) (Karimi et al. 2012, 2013; Lee et al. 2016).

New York State fish consumption advisories are issued by the New York State Department of Health (DOH) and are based on a risk management approach and guidelines (Table 3). If there is no specific advice for a water body, a general statewide advisory that recommends limiting sport fish consumption to up to four meals per month applies (because fish from all waters have not been tested, and fish may contain contaminants other than those that are routinely tested). In most cases, if a water body has a specific consumption advisory for the general population (men and older women), the sensitive population (women under 50 and children under 15) are advised not to consume any fish from that water body. Women under 50 and children under 15 are also advised to avoid consuming predator fish species from all water bodies in the high $\mathrm{Hg}$ regions of the Catskills and Adirondacks. There are fish consumption advisories for $\mathrm{Hg}$ in 92 water bodies New York State, with 62 of these in the Adirondacks (https://www.health.ny.gov/environmental/outdoors/fish/ health_advisories/).

\section{Mercury Concentrations in waters of New York State}

Mercury concentrations in the 15 species of fish with the highest levels in three major aquatic ecosystems of New
York State vary by species (Fig. 9). Fish Hg concentrations for Lake Erie and Lake Ontario over the past three decades, remain on average above the $0.22 \mathrm{ppm}$ (ww) advisory

a

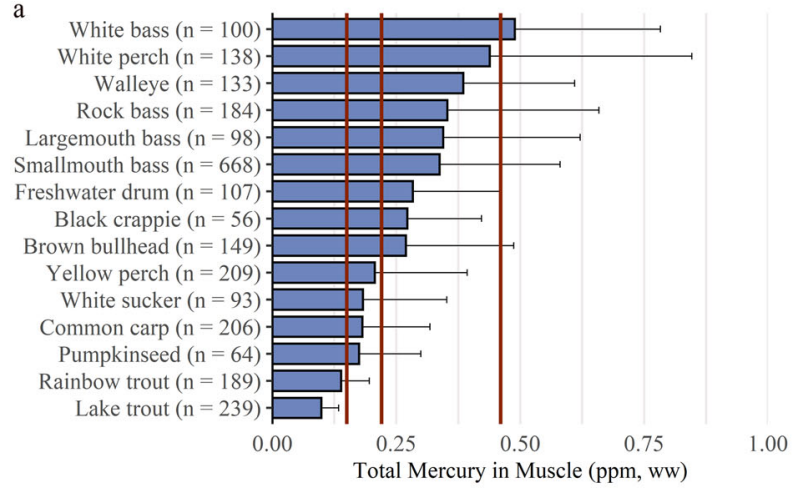

$\mathrm{b}$
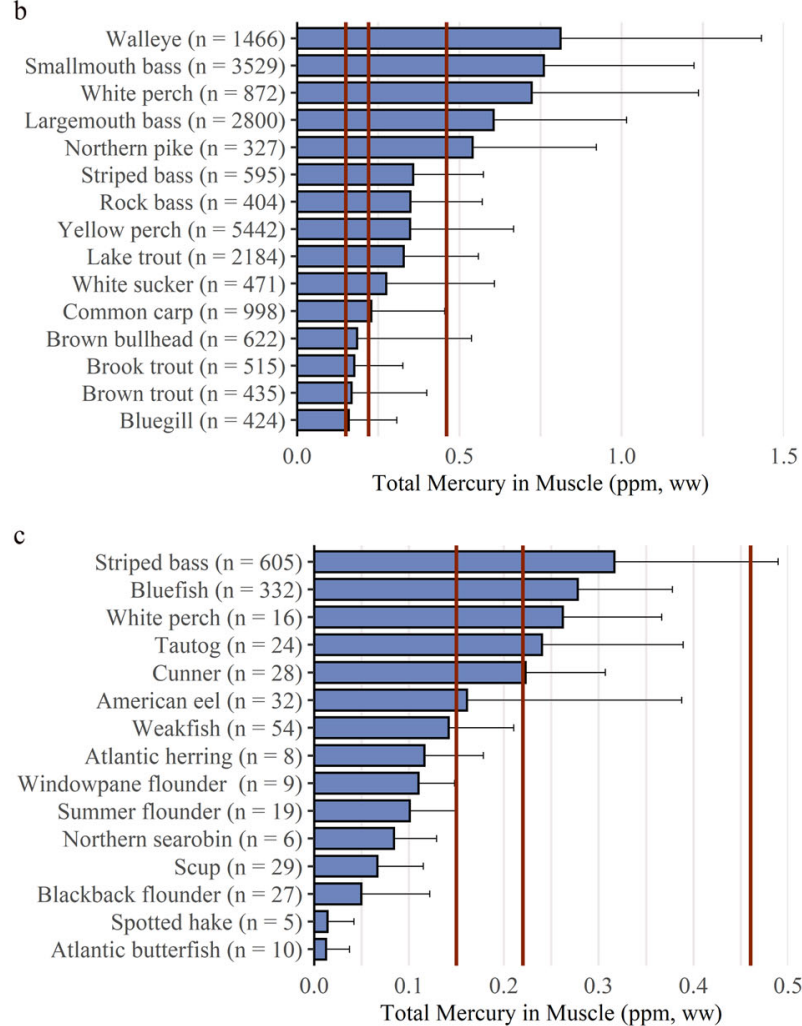

Fig. 9 a Mean concentrations and standard deviation of $\mathrm{Hg}$ in fish of Lake Erie and Lake Ontario of New York State $(n=2633)$. Three vertical lines indicate consumption advisory levels. The 0.15 and $0.46 \mathrm{ppm}$ vertical lines bracket the USEPA advisory levels. The mean $\mathrm{Hg}$ concentration of 9 of 15 species exceed the 0.22 ppm health threshold suggested by the Great Lakes Consortium (Table 3). b Mean concentrations and standard deviation of $\mathrm{Hg}$ in fish of inland waters of New York State $(n=21,084)$. Three vertical lines indicate consumption advisory levels. The 0.15 and $0.46 \mathrm{ppm}$ vertical lines bracket the USEPA advisory levels. The mean $\mathrm{Hg}$ concentration of 11 of 15 species exceed the $0.22 \mathrm{ppm}$ health threshold of the Great Lakes Consortium (Table 3). c Mean concentrations and standard deviation of $\mathrm{Hg}$ in fish of nearshore marine waters of New York State $(n=1204)$. Three vertical lines indicate consumption advisory levels. The 0.15 and $0.46 \mathrm{ppm}$ vertical lines bracket the USEPA advisory levels. The mean $\mathrm{Hg}$ concentration of 5 of 15 species exceed the $0.22 \mathrm{ppm}$ health threshold of the Great Lakes Consortium (Table 3) 
threshold suggested by the Great Lakes Consortium for 9 of the top 15 species analyzed (60\%), based on the NYSMD ( $n=2633$; Fig. 9a). Fish in the lower Great Lakes with the highest concentrations of $\mathrm{Hg}$ include white bass (Morone chrysops), white perch (Morone americana), and walleye (Sander vitreus).

There is considerable variability in fish $\mathrm{Hg}$ concentrations in inland waters of New York State, depending on region, species, and type of water body. Understanding this variability is important for interpreting patterns of exposure and monitoring trends for human and ecological health. Fish $\mathrm{Hg}$ concentrations in inland waters over the past three decades, remain on average above the $0.22 \mathrm{ppm}$ (ww) advisory threshold for 11 of the top 15 species (73\%) based on the NYSMD ( $n=21,084$; Fig. 9 b). Inland water fish with the highest concentrations of $\mathrm{Hg}$ include walleye, smallmouth bass (Micropterus dolomieu), and white perch. In the Finger Lakes region, fish $\mathrm{Hg}$ concentrations of most concern for human consumption are found in walleye and largemouth bass (Micropterus salmoides) but were not correlated with aquatic invertebrate $\mathrm{MeHg}$ concentrations (Razavi et al. 2020). In a survey of patterns of fish Hg across New York State, Millard et al. (2020b) found the highest concentrations in the Adirondack and Catskill regions.

In coastal marine waters, where most of the human fish consumption diet originates (over $90 \%$ in North America; Sunderland et al. 2018), fish $\mathrm{Hg}$ concentrations exceed $0.22 \mathrm{ppm}$ (ww) for 5 of the top 15 species analyzed (33\%), based on the NYSMD $(n=1204$; Fig. 9c). Patterns of coastal marine fish $\mathrm{Hg}$ are challenging to understand as sampling efforts are less robust than inland waters (Grieb et al. 2020). Chen et al. (2020) investigated the role of nutrient supply in fish $\mathrm{Hg}$ concentrations in coastal Long Island. In shallow coastal lagoons of Great South Bay and Jamaica Bay, they found that $\mathrm{Hg}$ inputs cycle through sediments which are continuously resuspended into the water column and redeposited back to sediments. They found that nutrient supply alters the uptake of $\mathrm{MeHg}$ at the algal base of the food chain through biodilution, while nitrogen appears to subsequently enhance trophic transfer of $\mathrm{MeHg}$ to prey fish.

\section{What are the spatial and temporal patterns of mercury in biota in New York State and to what extent do these reflect sensitivity to mercury inputs and changes in those inputs?}

\section{Ecosystem sensitivity to mercury}

Inorganic $\mathrm{Hg}$ enters ecosystems through atmospheric deposition, water releases (e.g., from wastewater treatment facilities, Glass et al. 1990), and leaching from land (e.g., from landfills and industrially contaminated sites; Kocman et al. 2017; Streets et al. 2017; Hsu-Kim et al. 2018; Obrist et al. 2018). Once in the environment, inorganic $\mathrm{Hg}$ can be transported to reducing zones (wetlands, sediments) and converted to $\mathrm{MeHg}$ by bacteria and archea (Gilmour et al. 2013a, 2013b; Podar et al. 2015). Methylmercury is toxic and can bioaccumulate at the base of the food web and biomagnify through the food chain resulting in elevated concentrations in the tissues of fish, wildlife, and humans, causing adverse health effects.

New York State and much of the Great Lakes basin is a net sink for $\mathrm{Hg}$ inputs (Denkenberger et al. 2012), with more $\mathrm{Hg}$ entering the basin through emissions and deposition than leaving through re-emission to the atmosphere or drainage losses. As a result, $\mathrm{Hg}$ deposited to the region accumulates in soils, and some of this legacy $\mathrm{Hg}$ is gradually leached to surface waters. Mercury recently deposited to the landscape tends to be more bioavailable than $\mathrm{Hg}$ long buried in soils and sediments (Hintelmann et al. 2002); although, $\mathrm{Hg}$ in soils can be mobilized by disturbances, such as storm runoff events, fires, and logging (Willacker et al. 2019; Denkenberger et al. 2020).

Mercury-sensitive areas with abundant forests receive elevated $\mathrm{Hg}$ inputs via throughfall and litterfall from atmospheric emissions and deposition to the forest canopy (Fig. 10). A fraction of the $\mathrm{Hg}$ deposited to sensitive landscapes is converted to $\mathrm{MeHg}$ largely in wetlands, sediments, and other favorable reducing environments. This conversion process is amplified under conditions of high organic matter, low oxygen, and low $\mathrm{pH}$, that are common in northern forest landscapes (Hsu-Kim et al. 2013; Fig. 10). Sulfate has also been shown to influence $\mathrm{MeHg}$ formation. Methylation rates increase up to concentrations of about $20 \mathrm{mg} / \mathrm{L}$ and decline under elevated sulfate concentrations in sulfur addition experiments (Gilmour and Henry 1991). However, in natural wetland settings where atmospheric deposition is the primary source of sulfate to the landscape, sulfate availability and $\mathrm{MeHg}$ are strongly correlated with no limitation evident (Åkerblom et al. 2013). Conditions where low oxygen, high organic matter, and sulfate reduction occur such as in wetlands, are particularly effective at mobilizing $\mathrm{MeHg}$, which may be further promoted by drying-rewetting cycles (Millard et al. 2020a; Wang et al. 2020). Furthermore, areas that supply elevated dissolved organic carbon (DOC) from decaying organic matter may facilitate the transport of inorganic and $\mathrm{MeHg}$ to downstream environments (Dittman et al. 2010; Burns et al. 2012; Millard et al. 2020a) and may be correlated with $\mathrm{MeHg}$ concentrations in macroinvertebrates (e.g., odonates; Nelson et al. 2020) and fish (Driscoll et al. 2007). Regions that have been acidified by acid deposition may be particularly sensitive to atmospheric $\mathrm{Hg}$ deposition, as sulfate from atmospheric deposition can serve as an important 


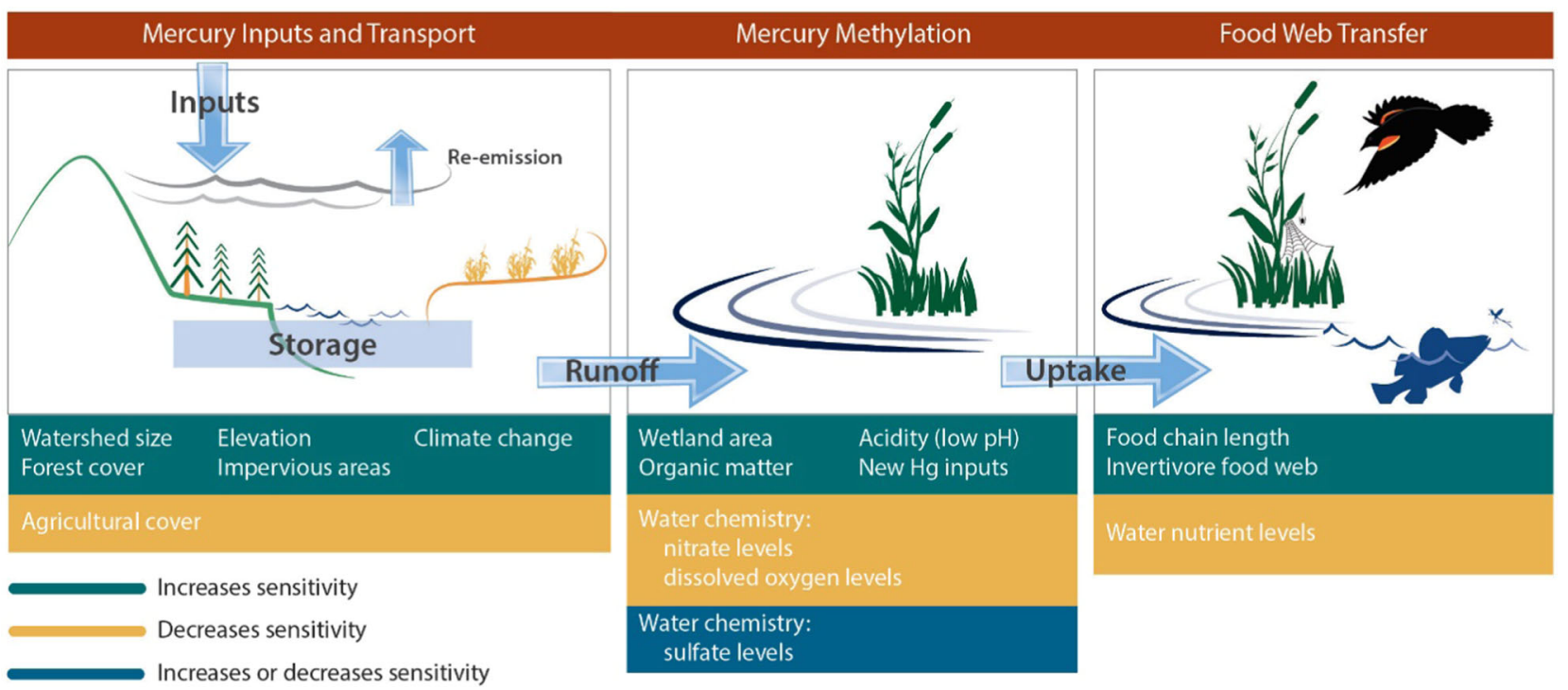

Fig. 10 Watershed $\mathrm{Hg}$ sensitivity connects landscape features related to $\mathrm{Hg}$ input and transport, methylation, and food web transfer for important factors in New York (Driscoll et al. 2007; Yu et al. 2011)

substrate for methylation (Wyn et al. 2009; Coleman Wasik et al. 2015), and Hg strongly bioaccumulates in zooplankton, fish, and loons at low pH (Driscoll et al. 2007; Yu et al. 2011). Finally, the nutrient supply and productivity of the water bodies can influence the concentration of $\mathrm{Hg}$ through biodilution and growth dilution (Driscoll et al. 2007, 2012; Chen et al. 2020).

In addition to variation in watershed sensitivity throughout the region, climatic variation and events can affect spatial patterns of $\mathrm{Hg}$ concentrations in biota. Swinton et al. (2020) described significant increases of $\mathrm{Hg}$ in smallmouth bass and yellow perch (Perca flavescens) on Lake Champlain and attributed to increased tributary loading of total suspended solids that resulted from a past storm runoff event.

In areas where atmospheric $\mathrm{Hg}$ deposition is moderate, effects on biota may be disproportionately high if conditions exist that promote $\mathrm{Hg}$ transport, methylation, and trophic transfer. Conversely, ecosystems with limited ability to transport inorganic $\mathrm{Hg}$ to zones of methylation or low methylation potential may have low levels of $\mathrm{MeHg}$ in biota despite considerable anthropogenic $\mathrm{Hg}$ contamination. The decoupling of inorganic $\mathrm{Hg}$ sources with $\mathrm{MeHg}$ production and bioaccumulation and biomagnification is evident at local (Evers et al. 2007) and landscape levels (Eagles-Smith et al. 2016). Millard et al. (2020a) found that dissolved organic matter and associated $\mathrm{Hg}$ was mobilized from soil to streamwater by watershed liming (calcium carbonate application). However, this enhanced transport did not result in increased $\mathrm{MeHg}$ concentrations in streamwater and stream macroinvertebrates due to limited zones of methylation (riparian areas, wetlands) within the watershed. The complexity of the $\mathrm{Hg}$ cycle challenges our ability to effectively predict concentrations in upper trophic level fish and wildlife from $\mathrm{Hg}$ concentrations in environmental media (soil, water, sediment; Gustin et al. 2016; Sunderland et al. 2016). Identifying appropriate bioindicators based on their relationship with sensitive ecosystems is a critical first step in assessing risk to ecological and human health through long-term $\mathrm{Hg}$ monitoring.

\section{Fish species}

Fish size class reflects different aspects of trophic transfer of $\mathrm{Hg}$ : (1) young fish $(<1$ year) reflect rapid changes in the availability of $\mathrm{MeHg}$ and local conditions; (2) mid-sized fish are important for assessing impacts to fish-eating wildlife such as common loons (Gavia immer), bald eagles (Haliaeettus leucocephalus), osprey (Pandion haliaetus), and North American river otter (Lontra canadensis); while (3) large fish that are at high trophic levels (i.e., game fish) are of particular concern for human health (Driscoll et al. 1994; Millard et al. 2020b).

The impacts on fish health and reproductive welfare are not well established, but have been summarized previously (Depew et al. 2012a, 2012b; Table 4). While fish $\mathrm{Hg}$ concentrations are commonly examined for their impacts on humans (i.e., muscle tissue) or for wildlife exposure (i.e., whole body), the $\mathrm{MeHg}$ concentrations in fish tissues also impact behavior, reproductive abilities, and overall health of fish. Fish may exhibit impaired reproductive success at relatively low $\mathrm{MeHg}$ concentrations as low as 0.04 ppm (ww) (Depew et al. 2012b) and may have adverse visible behavioral impacts at dietary $\mathrm{MeHg}$ concentrations of $0.50 \mathrm{ppm}$, ww or higher (Depew et al. 2012b). Lower reproductive success reduces the size and sustainability of healthy fish populations, which can 
Table 4 Screening benchmarks for piscivorous fish and birds for reproductive endpoints

\begin{tabular}{lll}
\hline Taxa & $\begin{array}{l}\text { Screening benchmark: } \\
\text { dietary } \mathrm{MeHg}(\mathrm{ppm}, \mathrm{ww})\end{array}$ & Endpoint of interest \\
\hline Fish & $>0.04$ & Impaired reproductive success (Depew et al. 2012b) \\
& $>0.50$ & Adverse effects behavior (Depew et al. 2012b) \\
Birds & $0.10-0.18$ & Adverse effects on behavior (Depew et al. 2012a) \\
& $0.18-0.40$ & Impaired reproductive success (Depew et al. 2012a) \\
& $>0.40$ & Reproductive failure (Depew et al. 2012a) \\
\hline
\end{tabular}

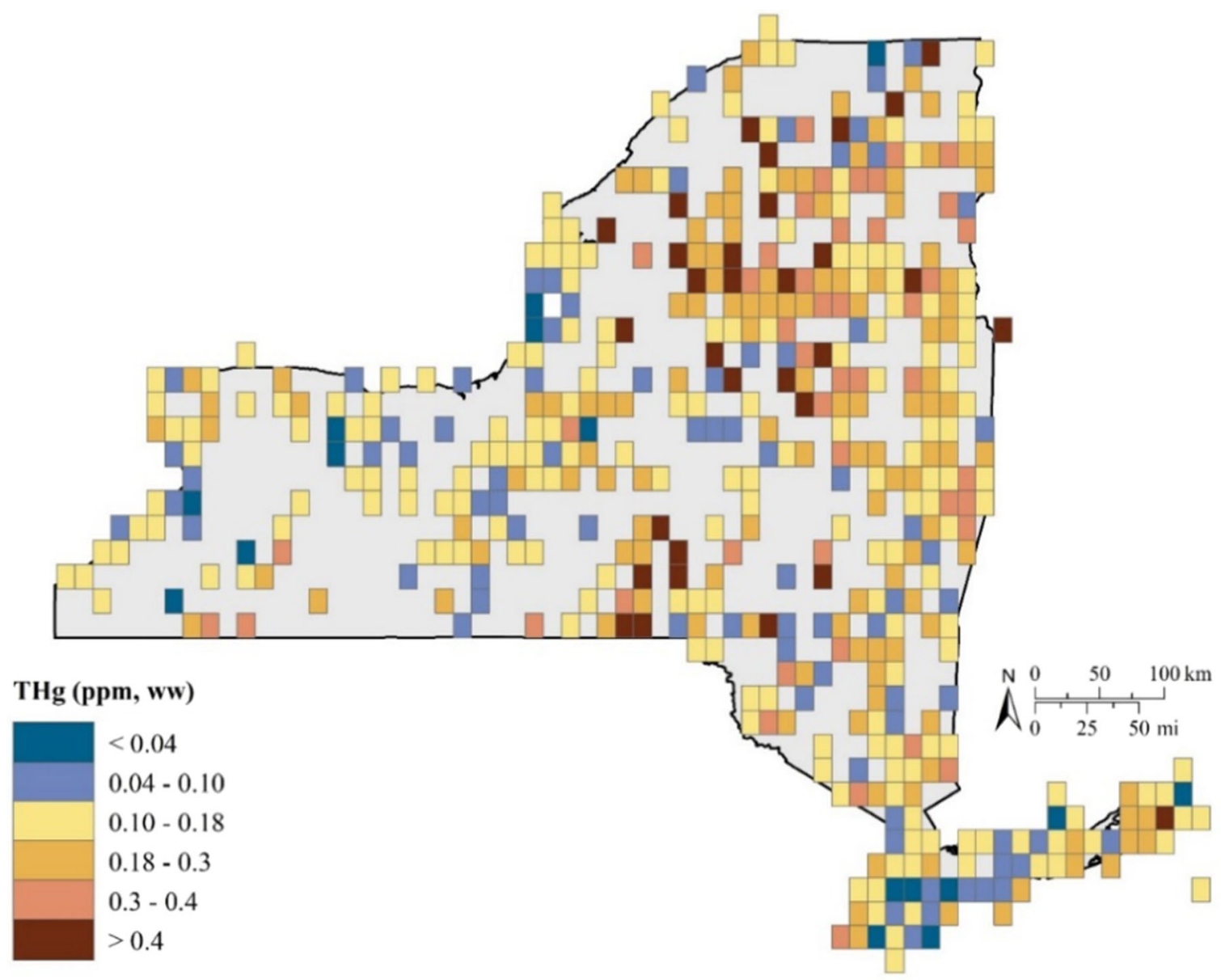

Fig. 11 A total of 33,502 fish samples were analyzed for $\mathrm{Hg}$ in New York from 1969 to 2017 representing 485 grids for the state (47\% represented). Of those grids, $80 \%, 42 \%$, and $6 \%$ had average $\mathrm{Hg}$

have adverse impacts on associated populations of piscivores and human recreational and commercial interests. Unlike freshwater fish, there have been few rigorous published studies evaluating toxicity of $\mathrm{MeHg}$ to marine fish (Scheuhammer et al. 2015).

Game fish are predatory fish that tend to be at high trophic levels (i.e., trophic levels 4 or 5) and therefore experience several levels of biomagnification of $\mathrm{MeHg}$. Human consumption of game fish in New York State usually includes species such as: walleye from Lake Erie and Lake Ontario; smallmouth and largemouth bass from inland concentrations above 0.10 , above 0.18 and above 0.40 , respectively, which are important for the health and reproductive welfare of avian piscivores (Depew et al. 2012a)

lakes and rivers; and bluefish (Pomatomus saltatrix) and striped bass (Morone saxatilis) from nearshore marine areas, all of which are well reflected in the NYSMD (Fig. 11).

There are marked spatial patterns of fish $\mathrm{Hg}$ concentrations across New York State (Figs 11, 12). In general fish $\mathrm{Hg}$ concentrations are highest in the Adirondack and Catskill regions and the Hudson Highlands of eastern New York State (Millard et al. 2020b). Land cover is an important determinant of this spatial pattern of fish $\mathrm{Hg}$ concentrations, with higher concentrations under forest land cover and lower under agricultural land cover (Fig. 


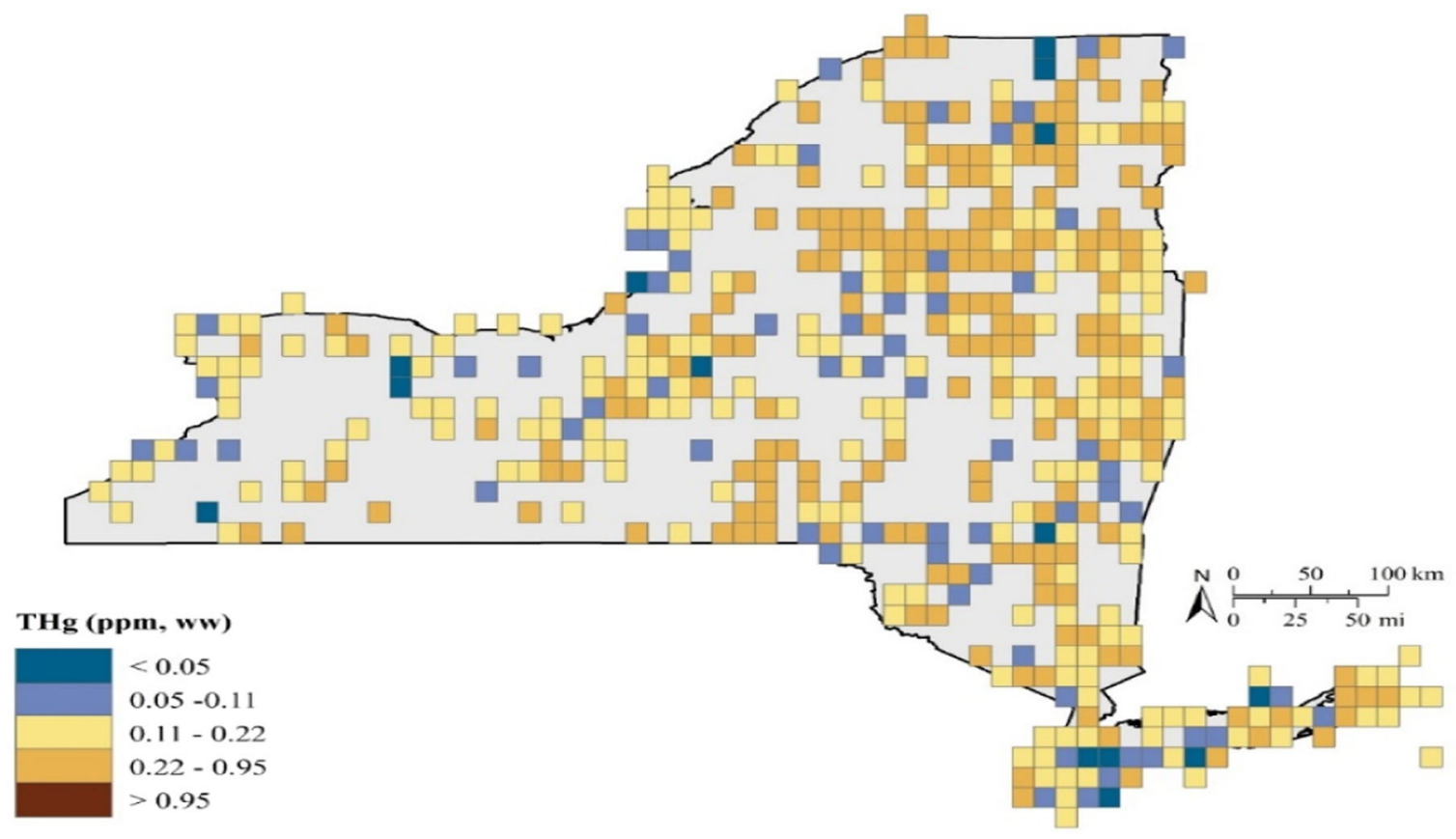

Fig. 12 A total of 25,909 game fish samples (38 species) were analyzed for $\mathrm{Hg}$ in New York from 1969 to 2017, representing 452 grid cells with $\mathrm{Hg}$ exposure data. Of these grids, 43 percent have average

13). Forest cover coincides with attributes that facilitate elevated fish $\mathrm{Hg}$ concentrations, including abundant wetlands and waters characterized by low nutrients and productivity. Conversely, agricultural lands coincide with lower fish $\mathrm{Hg}$ concentrations, partly related to fewer wetlands. Denkenberger et al. (2020) found marked variation in the forms of $\mathrm{Hg}$ in rivers draining into Lake Ontario. They observed strong partitioning of inorganic $\mathrm{Hg}$ by suspended matter. Watersheds high in agricultural and urban land cover that supplied large quantities of suspended particulate matter tended to largely transport particulate forms of $\mathrm{Hg}$, although this riverine response was muted by the presence of reservoirs. In contrast, in forested landscapes river $\mathrm{Hg}$ largely occurred in a dissolved form. Although land cover is an important determinate of fish $\mathrm{Hg}$ concentrations for areas with an abundance of forest cover, there is considerable variability in $\mathrm{Hg}$ concentrations in game fish (Figs 12,13).

Avian piscivores Birds that regularly forage on fish (piscivores) are often at risk from environmental $\mathrm{Hg}$ (Table 5). In New York State, larger avian piscivores (e.g., common loon, bald eagle, osprey) tend to have greater $\mathrm{Hg}$ body burdens than smaller avian piscivores (e.g., common merganser (Mergus merganser), belted kingfisher (Megaceryle alcyon), roseate tern Sterna dougallii). The greatest risk in New York State among these large piscivores is for common loons in the Adirondack Mountains (Schoch et al. 2020), and for bald eagles foraging in the Catskill game fish $\mathrm{Hg}$ concentrations over $0.22 \mathrm{ppm}$, with the Adirondack and Catskill Mountain regions and upper Susquehanna River Valley regularly having grids with elevated game fish $\mathrm{Hg}$ concentrations

Mountains and major rivers (e.g., Saint Lawrence, Hudson, Allegheny, and Susquehanna Rivers; DeSorbo et al. 2020; Fig. 14).

Avian invertivores Methylmercury from aquatic ecosystems can enter terrestrial food webs via predatory invertebrates, such as dragonflies and spiders (Seewagen et al. 2016; Nelson et al. 2020; Sauer et al. 2020a). Consumers of these and other invertebrates include avian invertivores, which have been identified to be of concern due to $\mathrm{MeHg}$ exposure (Evers et al. 2005; Jackson et al. 2011, 2015; Cristol and Evers 2020). The highest $\mathrm{Hg}$ concentrations and associated health risk in the state are for the following species: saltmarsh and seaside sparrows (Ammospiza caudacuta and A. maritima, respectively) in the estuaries of Long Island; palm warbler (Setophaga palmarum) and rusty blackbird (Euphagus carolinus) in the Adirondack Mountains; swamp sparrow (Melospiza georgiana) and redwinged blackbird (Agelaius phoeniceus) in the Catskill Mountains; and marsh wren (Cistothorus palustris) in the Montezuma Lakes complex (Fig. 15). Mercury body burdens for these species are at levels that may cause adverse reproductive impacts at a scale of concern.

\section{Habitats sensitive to mercury inputs}

Habitats where relatively small inputs of $\mathrm{Hg}$ can be transported, methylated and bioaccumulate to create areas of concern for fish, wildlife, and people are known as 
Fig. 13 Relationships of game cover. The upper panel shows game fish $\mathrm{Hg}$ concentrations as a function of forest land cover (Mean Game Fish THg) = $0.117119+0.001568$ (Mean

$F_{1,483}=87.54, R^{2}=0.1517, p<$ 0.001 ) with spatial distribution forest land cover on the right. The lower panel shows game function of agricultural land cover (Mean Game Fish THg) $=0.211629+-0.001341$ (Mean Percent Agriculture Cover), $F_{1,483}=18.89$, $\left.R^{2}=0.0354, p<0.001\right)$ with the spatial distribution of agricultural land cover on the right fish $\mathrm{Hg}$ concentrations with land Percent Forest Cover), fish $\mathrm{Hg}$ concentrations as a
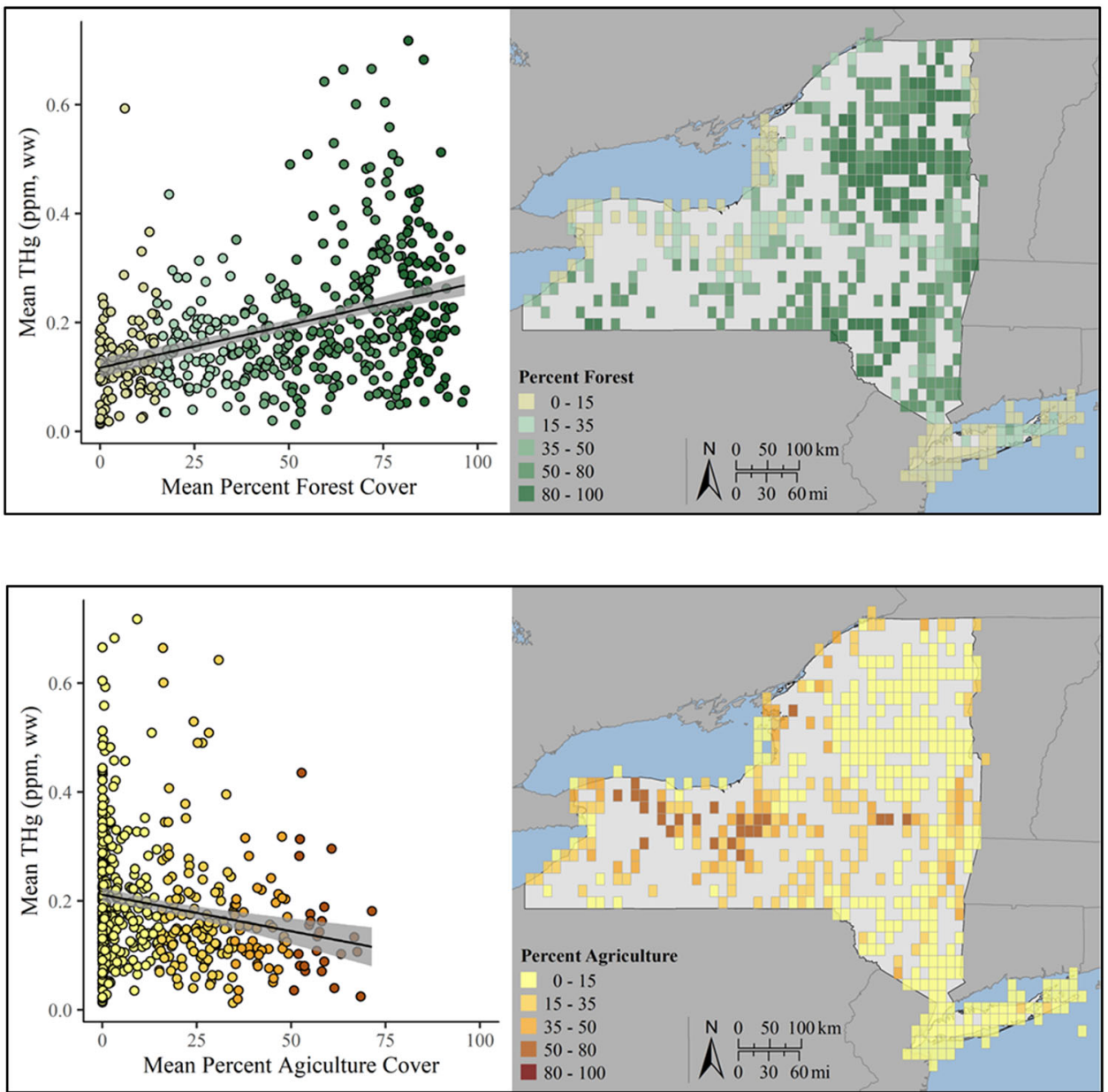

Avian Forage Guild of Interest Screening benchmark: THg in blood (ppm, ww)

for piscivorous and invertivorous birds (Evers 2018)

\begin{tabular}{lll}
\hline Piscivores & $<1.5$ & No observed effect level \\
& $1.5-2.0$ & $10 \%$ fewer fledged young \\
& $2.0-2.5$ & $20 \%$ fewer fledged young \\
& $2.5-3.0$ & $30 \%$ fewer fledged young \\
& $>3.0$ & $\geq 40 \%$ fewer fledged young \\
Invertivores & $<0.40$ & No observed effect level \\
& $0.40-0.70$ & $<10 \%$ fewer fledged young \\
& $0.70-1.2$ & $10 \%$ fewer fledged young \\
& $>1.2-1.7$ & $20 \%$ fewer fledged young \\
& $>1.7$ & $\geq 30 \%$ fewer fledged young
\end{tabular}

biological Hg hotspots (Evers et al. 2007). Mercury sensitive habitats identified in New York State based on observed $\mathrm{Hg}$ concentrations in biota include:

1. Estuaries: Mercury concentrations in blood and feather tissue from the saltmarsh sparrow on Long Island regularly exceeds levels that cause lower reproductive success in songbirds (Lane et al. 2020).
Saltmarsh and seaside sparrows are at particular risk because they often feed on spiders - a high $\mathrm{MeHg}$ food source (Cristol et al. 2008).

2. Sphagnum bogs and other wetlands: Wetlands are environments with efficient conversion of inorganic $\mathrm{Hg}$ to $\mathrm{MeHg}$ (Wang et al. 2020). In the Adirondack Park and elsewhere in northern New York State, sphagnum bogs generate elevated levels of $\mathrm{MeHg}$. 


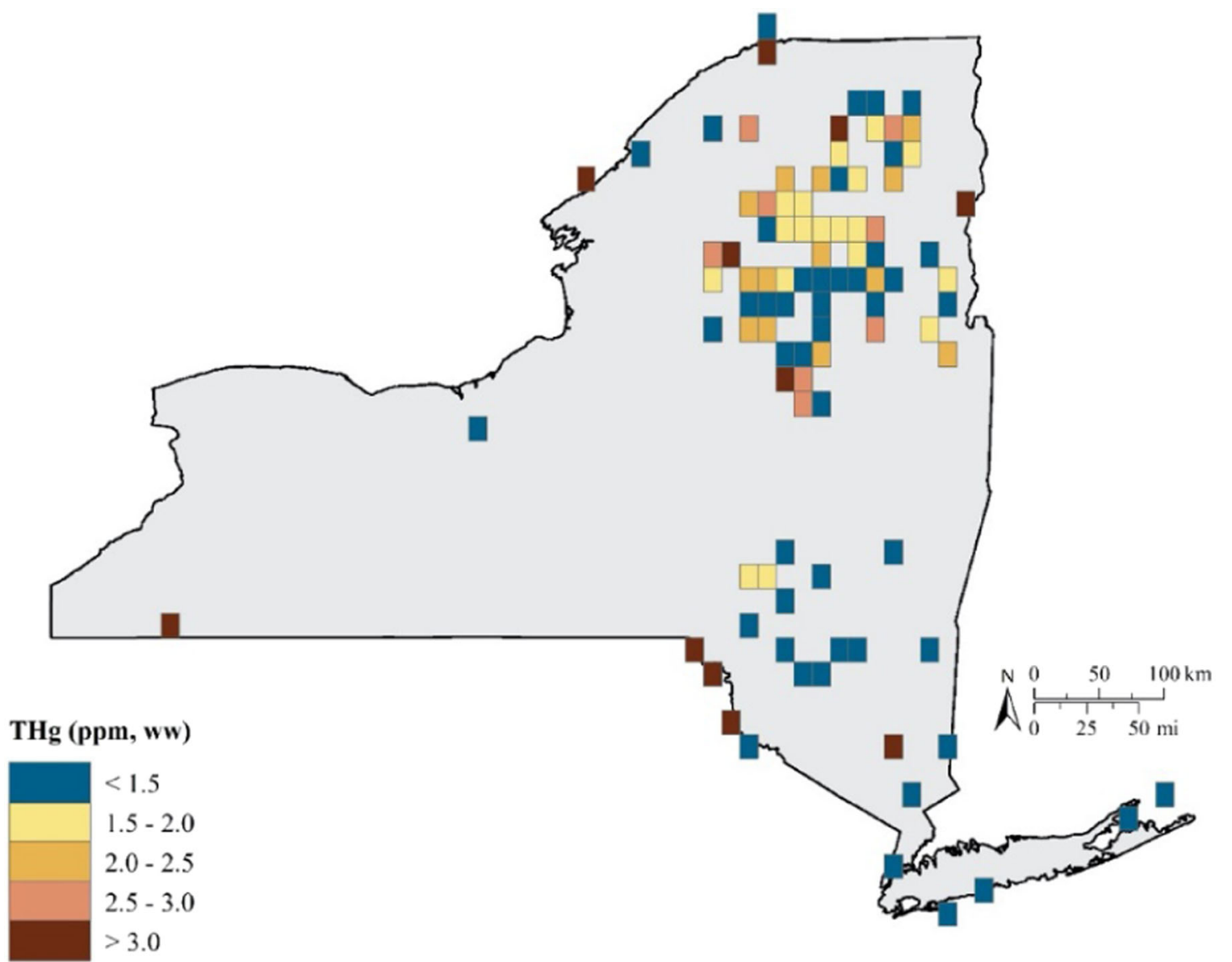

Fig. 14 Avian piscivores sampled in New York State from 1970 through 2017. Of the grids sampled for avian piscivores $(n=97), 52$ percent of the grids they occupy were above $1.5 \mathrm{ppm}$ of total $\mathrm{Hg}$ in

The transfer of $\mathrm{MeHg}$ within and between aquatic and terrestrial food webs are important pathways for biomagnification and create risk for some avian invertivores such as the palm warbler (Setophaga palmarum) and rusty blackbird (Edmonds et al. 2010; Perkins et al. 2020; Sauer et al. 2020a).

3. High-elevation boreal forests: Montane habitats generally receive higher rates of atmospheric $\mathrm{Hg}$ deposition due to increased precipitation quantity and cloud cover (Blackwell et al. 2014; Gerson et al. 2017). An elevational gradient of increasing $\mathrm{Hg}$ exposure was found in songbirds including Swainson's (Catharus ustulatus), hermit (C. guttatus), and Bicknell's ( $C$. bicknelli) thrush on Whiteface Mountain in the Adirondack Park-although the risk to reproductive success is minor (Rimmer et al. 2005, 2020; Sauer et al. 2020b).

4. Streams and rivers in forested watersheds: Based on macroinvertebrates (e.g., odonate larvae) and fish, watersheds with higher forest cover and wetlands have higher $\mathrm{MeHg}$ concentrations that frequently their blood (equivalent to a loss of $10 \%$ of reproductive success), while $33 \%$ were above $2.0 \mathrm{ppm}$ or $20 \%$ loss, and $20 \%$ over $2.5 \mathrm{ppm}$ or $30 \%$ loss (Table 5)

exceed fish-related guidelines for human health and wildlife (Riva-Murray et al. 2020a, 2020b; Millard et al. 2020b). The belted kingfisher (Megaceryle alcyon) and Louisiana waterthrush (Parkesia motacilla) are good bioindicators for such systems (Evers et al. 2005; Jackson et al. 2011).

5. Acidic lakes with wetland shorelines in forested watersheds: While most lakes have the potential for high trophic level biota with elevated $\mathrm{Hg}$ body burdens, oligotrophic lakes with a $\mathrm{pH}$ below 6.3, with significant shoreline wetlands, and/or fluctuating water levels are of greatest concern for piscivorous species such as game fish (Millard et al. 2020b), the common loon (Schoch et al. 2020) and bald eagle (DeSorbo et al. 2020).

The Northeastern Highlands Ecoregion (particularly the Adirondack and Catskill regions) of New York State are particularly sensitive to $\mathrm{Hg}$ pollution. The impact of $\mathrm{Hg}$ emissions and deposition is exacerbated by watershed, stream, and lake characteristics in areas with abundant forests 


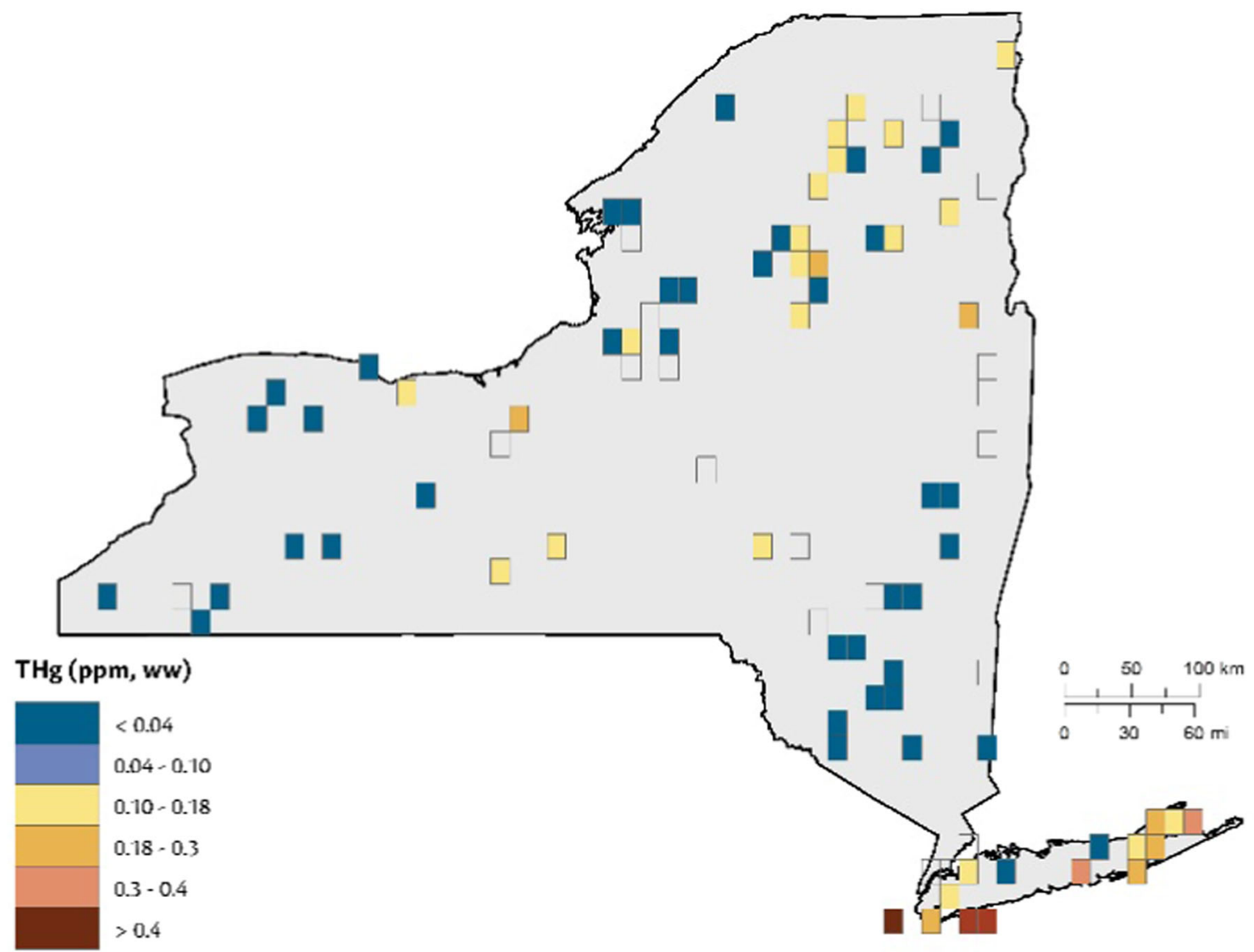

Fig. 15 From 1970 to 2017, a total of 93 grids (representing 9\% coverage) have been sampled for avian invertivores. Target songbirds were found in 73 of these grids, and $44 \%$ of these birds had $>0.4 \mathrm{ppm}$

and wetlands - areas that enhance $\mathrm{Hg}$ inputs, transport, methylation, and uptake to elevate concentrations in aquatic food webs resulting in elevated $\mathrm{Hg}$ concentrations in game fish and avian piscivores and invertivores. These regions have also been impacted by historical acid deposition.

\section{Long-term changes in mercury in biota}

Multiple bioindicators are needed to confidently track changes. For some biota, such as songbirds, long-term trends in $\mathrm{Hg}$ exposure can be tracked with museum specimens and compared with recent sampling (Dzielski et al. 2020; Perkins et al. 2020). There is strong evidence that long-term increases in environmental $\mathrm{Hg}$ loads (Drevnick et al. 2012) and subsequent effects have increased significantly since the mid-1800s (Perkins et al. 2020), but linking $\mathrm{Hg}$ body burdens of biota in New York State with $\mathrm{Hg}$ emission patterns remains challenging (Dzielski et al. 2020).

Time series analysis revealed limited significant trends in $\mathrm{Hg}$ concentrations in fish or birds for most ecoregions of New York State (Fig. 16). The most consistent significant total blood $\mathrm{Hg} ; 17 \%$ were $>0.7 \mathrm{ppm} ; 7 \%$ were $>1.2 \mathrm{ppm}$; and $4 \%$ were $>1.7$ ppm (Table 5)

decreasing trends were evident across multiple fish species in the Eastern Great Lakes Lowlands (Fig. 16). These trends may reflect decreases in releases of $\mathrm{Hg}$ to the Great Lakes region coupled with decreases in atmospheric $\mathrm{Hg}$ deposition. Ye et al. (2020) found that lands immediately adjacent to the Great Lakes had among the highest atmospheric $\mathrm{Hg}$ deposition in New York State (Fig. 6). To a lesser extent decreasing trends were also evident for largemouth bass, white perch and yellow perch in the Northern Highlands. These decreasing trends are tempered by increasing concentrations of $\mathrm{Hg}$ in northern pike (Esox lucius; Fig. 16). Trends in fish $\mathrm{Hg}$ concentrations that are inconsistent with those in atmospheric $\mathrm{Hg}$ deposition are quite common and can result from the influence of many factors including response lags, climate variation, and shifts in food sources (Wang et al. 2019).

Game fish have been monitored for $\mathrm{Hg}$ in the Great Lakes adjacent to New York State for almost 50 years (Richter and Skinner 2020; Fig. 16). Over this period, many environmental factors influencing $\mathrm{Hg}$ bioavailability have changed, including $\mathrm{Hg}$ deposition rates, climate, hydrology and lake stage, surrounding terrestrial habitat, and food webs. Using fillet 
Fig. 16 Long-term trends in $\mathrm{Hg}$ concentrations on fish and birds in ecoregions of New York State. A blue square indicates a significant decreasing trend for a given species, a red square a significant increasing trend, and a gray square no significant trend

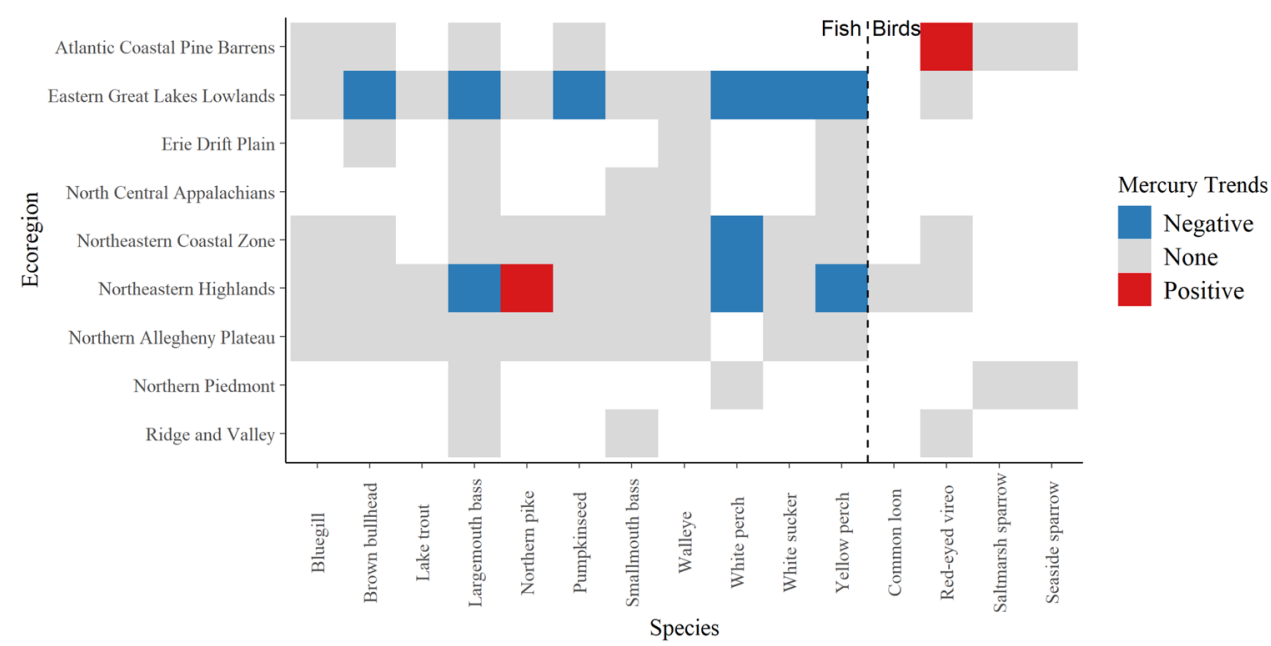

concentrations, $\mathrm{Hg}$ exposure levels were tracked in 16 fish species over a 40-year period to determine annual changes in fish exposure risk and human risk from consumption (Richter and Skinner 2020). The steepest declines in Hg concentrations occurred from the 1970s-80s for yellow perch $(n=999)$ and largemouth bass $(n=1344)$. From the 1980s onward, fish $\mathrm{Hg}$ concentrations have continued to generally decline. Zhou et al. (2017) also found decreasing $\mathrm{Hg}$ trends (in lake trout, Salvelinus namaycush, and walleye) across the Great Lakes for the past four decades, except in the past decade where there were increases for Lake Erie and Lake Ontario.

Common loons have been monitored for $\mathrm{Hg}$ exposure in the Adirondack Park since 1998 (Schoch et al. 2020) and optimal sampling strategies are now identified, although lake acidity (Yang et al. 2020) and likely other abiotic factors (Buxton et al. 2020) need to be considered when evaluating trends. Mercury can be elevated in the fish that loons consume, which may adversely affect loon populations. As the top predator in montane lake ecosystems, loons show $\mathrm{Hg}$ concentrations that are indicative of risk throughout their breeding range in New York State. Using $\mathrm{Hg}$ in blood and egg samples from breeding loons in 116 lakes throughout Adirondack Park from 1998 to 2016, Schoch et al. (2020) tracked MeHg availability and evaluated risk to the common loon (Fig. 16). Concentrations of $\mathrm{Hg}$ in breeding loons increased 5.7 percent per year from 1998 to 2010, and then stabilized from 2010 to 2016. Recovery of $\mathrm{Hg}$ concentrations in loons has been delayed compared to trends in local atmospheric $\mathrm{Hg}$ deposition (Fig. 8), even though there has been a long-term recovery of lakes in the Adirondack region to decreases in acidic deposition (Waller et al. 2012; Driscoll et al. 2016).

Mercury exposure high enough to cause reproductive impacts has been identified in saltmarsh sparrows (Lane et al. 2011, 2020), a species classified as endangered on the International Union for Conservation of Nature (IUCN) Red
List. Since 2000, monitoring projects have tracked $\mathrm{Hg}$ concentrations in saltmarsh sparrow blood to understand how the risk of $\mathrm{Hg}$ effects has changed over time across Long Island (Lane et al. 2020; Fig. 16). Risk of Hg exposure is declining, but remains elevated across New York State marshes, and there is considerable variation in blood $\mathrm{Hg}$ concentrations within the breeding season. Concentrations peak in mid-July and such seasonal patterns need to be considered for long-term monitoring. Most marshes have cyclical patterns of annual $\mathrm{Hg}$ exposure, which may relate to annual variation in local $\mathrm{Hg}$ deposition, tidal marsh flooding, and variation in food availability.

For fish species, more than 50 years of $\mathrm{Hg}$ data are available, and are especially robust for yellow perch and largemouth bass, which show statistically significant declines statewide based on the NYSMD and for the Eastern Great Lakes Lowlands, specifically, the slope parameters are significant for yellow perch $(\beta=-0.022$ $[-0.033,-0.011])$ and largemouth bass $(\beta=-0.015$ $[-0.030,0.000])$. For birds, the temporal span of data varies from six to more than 20 years among species. The red-eyed vireo (Vireo olivaceus) sampled in Long Island's forests shows an increasing trend (slope parameter $\beta=0.26,95 \%$ credible interval $=[0.03,0.49])$, yet in nearby estuaries, the saltmarsh sparrow shows a declining trend (slope parameter $\beta=-0.055,95 \%$ credible interval $=[-0.144,0.036])$. Ultimately, ecoregions may respond differently to changes in environmental $\mathrm{Hg}$ loads, as will taxa. Therefore, use of fish and bird bioindicators for multiple ecoregions is essential to understand and track the availability of $\mathrm{MeHg}$ across New York State.

Mercury concentrations in biota of New York State have declined or remained constant over the last four decades, concurrent with decreased air emissions from regional and U.S. sources (Figs. 4, 5, 7, 8). After initial declines, however, concentrations of $\mathrm{Hg}$ in some fishes and birds from 
certain locations have increased in recent years, revealing the complexities of trajectories of $\mathrm{Hg}$ recovery (Zhou et al. 2017). Because there is not a demonstrated relationship between atmospheric $\mathrm{Hg}$ deposition and biotic uptake (Rimmer et al. 2020; Dzielski et al. 2020), Hg monitoring in biota is of ongoing importance.

\section{Long-term influences from climate change}

The results of these studies suggest that climate change could potentially affect future $\mathrm{Hg}$ deposition. For example, climate predictions for the northeastern United States anticipate increased precipitation amounts and increased temperature, which may in turn drive increases in $\mathrm{Hg}$ deposition. This projection underscores the importance of further reduction of anthropogenic $\mathrm{Hg}$ emissions in order to address the potential influence climate change may have on $\mathrm{Hg}$ exposure.

Factors affecting $\mathrm{Hg}$ transport, transformations, and bioaccumulation include: (1) increases in rainfall amount and variability, which create conditions of increased transport and leaching from soil and enhanced wet-dry cycles that augment methylation (Burns et al. 2014a; Watras et al. 2020; Wang et al. 2020); (2) enhanced growth of trees which is a major pathway for atmospheric $\mathrm{Hg}$ deposition (Blackwell et al. 2014; Jiskra et al. 2018); (3) higher water temperatures which are associated with higher $\mathrm{Hg}$ methylation rates and fish $\mathrm{Hg}$ concentrations, and strengthen and extend the duration of thermal stratification in lakes which may increase depletion of dissolved oxygen and methylation of $\mathrm{Hg}$ (Bodaly et al. 1993; Warren et al. 2016); and (4) increases in water temperature and fluctuating water tables in stream water enhancing MeHg concentrations (Burns et al. 2014b).

Recent evidence suggests that climate-related factors influence patterns of $\mathrm{Hg}$ exposure in aquatic and terrestrial biota. Increasing temperature and rainfall, combined with shifting habitat distributions, will shape future $\mathrm{Hg}$ deposition, transport, and methylation, and in turn, exposure risk. Understanding how these large-scale factors will play out on smaller spatial and temporal scales will require continued research and monitoring (Swinton and NierzwickiBauer 2020; Adams et al. 2020).

\section{What are key mercury policy connections in New York State and beyond?}

While the timing and magnitude of the response will vary, further controls on $\mathrm{Hg}$ emission sources are expected to lower $\mathrm{Hg}$ concentrations in food webs, yielding multiple benefits to fish, wildlife, and people in New York State and the surrounding region. Improvements are anticipated to be greatest for inland surface waters and will be roughly proportional to declines in $\mathrm{Hg}$ deposition (Knightes et al.
2009), which most closely track trends in regional and U.S. air emissions. This scientific synthesis of $\mathrm{Hg}$ in air, water, invertebrates, fish, and birds characterizes the status and effects of $\mathrm{Hg}$ pollution across New York State. Information from existing data and $\mathrm{Hg}$ monitoring programs can inform many of the regional, national, and global policy initiatives currently implemented or in process.

\section{U.S. mercury emissions}

Mercury pollution in the U.S. is regulated by an array of state and federal regulations (see: http://www.epa.gov/hg/). There has been substantial progress in regulatory efforts to decrease $\mathrm{Hg}$ emissions from major source categories. Specifically, the USEPA has: (1) finalized maximum standards for $\mathrm{Hg}$ from coal-fired power plants; (2) created national emissions standards for hazardous air pollutants for gold ore processing and production facilities; (3) finalized rules to control $\mathrm{Hg}$ emissions from Portland cement manufacturing facilities; and (4) proposed new source performance standards and emissions guidelines for new and existing sewage sludge incinerators. Mercury reductions from electric utilities have also occurred indirectly through controls on emissions of sulfur dioxide and nitrogen oxides (Zhang et al. 2016).

The MATS rule has resulted in marked decreases in $\mathrm{Hg}$ emissions from electric utilities (Fig. 4). This rule is integral to meeting U.S. commitments under the international Minamata Convention on Mercury. In 2020, the USEPA decided to rescind the finding that regulatory $\mathrm{Hg}$ is "appropriate and necessary", a modification that has led to challenges to the MATS rule and its potential repeal.

Many states have implemented their own regulations to limit $\mathrm{Hg}$ emissions, which have often been more stringent than federal regulations (Rallo et al. 2012). One novel approach is use of provisions of the Clean Water Act and establishing a total maximum daily load (TMDL) for $\mathrm{Hg}$ that can have an indirect effect on emissions (https://neiwpcc.org/ our-programs/nps/mercury/mercury-tmdl/). New York State and the six New England states began implementation of the Northeast Regional Mercury Total Maximum Daily Load in 2007 to reduce fish $\mathrm{Hg}$ concentrations in all surface water bodies to less than $0.3 \mathrm{ppm}$. The TMDL effort has harnessed and focused efforts within the Northeast to measure and identify impaired water bodies and to reduce $\mathrm{Hg}$ use and emissions within the region but has encountered some hurdles as well because of limited ability of the states to affect Hg emissions outside their region (Selin 2011).

\section{Minamata Convention on Mercury}

The Minamata Convention on Mercury is a global treaty intended to protect human health and the environment from anthropogenic emissions and releases of $\mathrm{Hg}$. In 2013 the 
text of the Convention was approved by delegates representing nearly 140 countries. The Convention was adopted and signed in 2013 at the Diplomatic Conference in Kumamoto, Japan. The Convention entered into force in 2017. More than 120 countries have ratified or accessioned the Convention, including the United States (see https://www.mercuryconvention.org/). Pursuant to Article 23 of the Minamata Convention, a governing body called the Conference of the Parties (COP) was established. The COP is responsible for advancing implementation of the Convention and for keeping the Convention under continuous review and evaluation. To evaluate the effectiveness of the Minamata Convention's success, $\mathrm{Hg}$ monitoring efforts at the global level are planned (Evers and Sunderland 2019). Decisions relevant to these responsibilities are made during meetings of the COP. The Minamata Convention is expected to provide substantial benefits to the U.S. in excess of $\$ 100$ billion as cumulative lifetime health benefits as well as economic benefits, primarily due to improved health outcomes from consumption of marine fish (Giang and Selin 2016). Residents of New York are expected to realize substantial benefits from implementation of the Minamata Convention due to anticipated decreases in atmospheric $\mathrm{Hg}$ deposition from global sources (Lin et al. 2012), as well because of state's abundant coastal marine waters and previously identified high levels of marine fish consumption and associated high $\mathrm{Hg}$ blood levels in coastal areas (Mahaffey et al. 2009).

\section{Science informs policy—a mercury policy timeline}

There has been substantial progress in regulating $\mathrm{Hg}$ use, emissions, and releases over the past four decades. The scientific understanding of the harm to human health and the environment from $\mathrm{Hg}$ increased in the 1980s and 1990s, when U.S. policies to control $\mathrm{Hg}$ trade, its use in products and industry, and its release in waste streams began to be instilled at state and regional levels (e.g., the Great Lakes and New England).

In parallel, local policymaking and national assessment of $\mathrm{Hg}$ effects were conducted that would eventually result in the MATS rule. Efforts to monetize the benefits of controls on $\mathrm{Hg}$ releases have found that the direct health benefits of controls are sizable (Giang and Selin 2016). The MATS rule was important in establishing a science-based policy for the United States to participate in a leadership role for creating the Minamata Convention on Mercury. Tracking Hg in the environment and its impact on human health is an important next step in the control of $\mathrm{Hg}$ use, emissions, and releases. The relationships among key compartments such as air, biota, and humans are complex and often not linear.

The complexity and interactions of the drivers behind the transport of $\mathrm{Hg}$, methylation, and subsequent transfer through the food web requires monitoring to understand and evaluate the success of the MATS rule and the Minamata Convention. Tracking Hg over time also requires carefully designed sampling approaches that can generate standardized and comparable data over time. Preliminary approaches are being generated for the Minamata Convention (e.g., biota; Evers and Sunderland 2019) and with an expectation of initiation in the near future.

Acknowledgements This paper was supported by the New York State Energy Research and Development Authority (NYSERDA) Agreement Number 124842. We would like to thank Greg Lampman for coordinating New York State $\mathrm{Hg}$ research over the many years, including the following NYSERDA studies that are also supported in this special issue and featured in this paper (NYSERDA Agreement Numbers: 9956, 16296, 33075, 33075A, 34357, 34358, 37346, 40515, 50462, 50778, 108229, and 113882). To best meet "Fair Principle" objectives, all data associated with this special issue can be accessed under the project "NYSERDA Synthesis of Environmental Mercury Loads in New York State (1969-2017)" at: https://data.ny.gov/ Energy-Environment/NYSERDA-Synthesis-of-Environmental-

Mercury-Loads-i/v475-sje9. Data were collected by innumerable biologists over the past 50 years and without their work this manuscript would not exist. Any use of trade, product, or firm names is for descriptive purposes only and does not imply endorsement by the U.S. Government. The assistance of Connor Olson in the processing of information on emissions and air concentrations and wet deposition of $\mathrm{Hg}$ is greatly appreciated.

\section{Compliance with ethical standards}

Conflict of interest The authors declare that they have no conflict of interest.

Publisher's note Springer Nature remains neutral with regard to jurisdictional claims in published maps and institutional affiliations.

Open Access This article is licensed under a Creative Commons Attribution 4.0 International License, which permits use, sharing, adaptation, distribution and reproduction in any medium or format, as long as you give appropriate credit to the original author(s) and the source, provide a link to the Creative Commons license, and indicate if changes were made. The images or other third party material in this article are included in the article's Creative Commons license, unless indicated otherwise in a credit line to the material. If material is not included in the article's Creative Commons license and your intended use is not permitted by statutory regulation or exceeds the permitted use, you will need to obtain permission directly from the copyright holder. To view a copy of this license, visit http://creativecommons. org/licenses/by/4.0/.

\section{References}

Adams EM, Sauer AK, Lane O, Regan K, Evers DC (2020) The effects of climate, habitat, and trophic position on methylmercury bioavailability for New York songbirds. Ecotoxicology. https:// doi.org/10.1007/s10646-019-02151-w

Adams EM, Gulka JE, Yang Y, Burton MEH, Burns DA, Buxton V, Cleckner L, DeSorbo C, Driscoll CT, Evers DC, Fisher N, Lane O, Mao H, Riva-Murray K, Millard G, Razavi R, Richter W, 
Sauer AK, Schoch N (2020) Distribution and trends of mercury in aquatic and terrestrial biota of New York, USA: a synthesis of 50 years of research and monitoring. BRI Report No. 2020-24

Åkerblom S, Bishop K, Björn E, Lambertsson L, Eriksson T, Nilsson MB (2013) Significant interaction effects from sulfate deposition and climate on sulfur concentrations constitute major controls on methylmercury production in peatlands. Geochim Cosmochim Acta 102:1-11. https://doi.org/10.1016/j.gca.2012.10.025

Amos HM, Jacob DJ, Streets DG, Sunderland EM (2013) Legacy impacts of all-time anthropogenic emissions on the global mercury cycle. Glob Biogeochem Cycles 27:410-421

Blackwell BD, Driscoll CT, Maxwell JA, Holsen TM (2014) Changing climate alters inputs and pathways of mercury deposition to forested ecosystems. Biogeochemistry 119:215-228

Blackwell BD, Driscoll CT (2015) Deposition of mercury in forests along a montane elevation gradient. Environ Sci Technol 49:5363-5370

Bloomfield JA, Quinn SO, Scrudato RJ, Long D, Richards A, Ryan F (1980) Atmospheric and watershed inputs of mercury to Cranberry Lake, St. Lawrence County, New York. In: Toribara TY, Miller MW, Morrow PE (eds) Polluted rain. Environmental science research. Springer, Boston, MA. https://doi.org/10.1007/978-1-4613-3060-8_9

Bodaly RA, Rudd JWM, Fudge RJP, Kelly CA (1993) Mercury concentrations in fish related to size of remote Canadian shield lakes. Can J Fisheries Aquat Sci 50:980-987

Bourtsalas AT, Themelis NJ (2019) Major sources of mercury emissions to the atmosphere: the US case. Waste Manag 85:90-94

Buck DG, Evers DC, Adams E, DiGangi J, Beeler B, Samánek J, Petrlik J, Turnquist MA, Speranskaya O, Regan K, Johnson S (2019) A global-scale assessment of fish mercury concentrations and the identification of biological hotspots. Sci Total Environ 687:956-966

Burns DA, Riva-Murray K, Bradley PM, Aiken GR, Brigham ME (2012) Landscape controls on total and methyl $\mathrm{Hg}$ in the upper Hudson River basin, New York, USA. J Geophys Res Biogeosciences 117. https://doi.org/10.1029/2011JG001812

Burns DA, Woodruff LG, Bradley PM, Cannon WF (2014a) Mercury in the soil of two contrasting watersheds in the Eastern United States. PloS ONE 9:e86855

Burns DA, Nystrom EA, Wolock DM, Bradley PM, Riva-Murray K (2014b) An empirical approach to modeling methylmercury concentrations in an Adirondack stream watershed. J Geophys Res Biogeosciences 119:1970-1984

Buxton VL, Evers DC, Schoch N (2020) The influence of biotic and abiotic factors on banded common loon (Gavia immer) reproductive success in a remote, mountainous region of the northeastern United States. Ecotoxicology

Cain A, Morgan JT, Brooks N (2011) Mercury policy in the Great Lakes states: past successes and future opportunities. Ecotoxicology 20:1500-1511

Carpenter B, Gelman A, Hoffman MD, Lee D, Goodrich B, Betancourt M, Brubaker M, Guo J, Li P, Riddel A (2017) Stan: a probabilistic programming language. J Stat Softw 76. https://doi. org/10.18637/jss.v076.i01

Chen CYKB, Shaw AL, Curtis A, Taylor MS, Montedesca MR, Driscoll CT (2020) The influence of nutrient loading on methylmercury availability in long island estuaries. Environ Pollut, (in press). https://doi.org/10.1016/j.envpol.2020.11510

Choi H-D, Holsen TM, Hopke PK (2008) Atmospheric mercury (Hg) in the Adirondacks: concentrations and sources. Environ Sci Technol 42:5644-5653

Coleman Wasik JK, Engstrom DR, Mitchell CPJ, Swain EB, Monson BA, Balogh SJ, Jeremiason JD, Branfireun BA, Kolka RK, Almendinger. JE (2015) The effects of hydrologic fluctuation and sulfate regeneration on mercury cycling in an experimental peatland. J Geophys Res Biogeosciences 120:1697-1715
Cristol DA, Brasso RL, Condon AM, Fovargue RE, Friedman SL, Hallinger KK, Monroe AP, White AE (2008) The movement of aquatic mercury through terrestrial food webs. Science 320:335-335

Cristol DA, Evers DC (2020) The impact of mercury on North American songbirds: effects, trends, and predictive factors. Ecotoxicology 29:1107-1116

Denkenberger JS, Driscoll CT, Branfireun BA, Eckley CS, Cohen M, Selvendiran P (2012) A synthesis of rates and controls on elemental mercury evasion in the Great Lakes Basin. Environ Pollut 161:291-298

Denkenberger J, Fakhraei H, Branfireun B, Mason E, Driscoll CT (2020) Watershed influences on mercury in tributaries to lake Ontario. Ecotoxicology. https://doi.org/10.1007/s10646-019-02157-4

Depew DC, Basu N, Burgess NM, Campbell LM, Evers DC, Grasman KA, Scheuhammer AM (2012a) Derivation of screening benchmarks for dietary methylmercury exposure for the common loon (Gavia immer): rationale for use in ecological risk assessment. Environ Toxicol Chem 31:2399-2407

Depew DC, Basu N, Burgess NM, Campbell LM, Devlin EW, Drevnick PE, Hammerschmidt CR, Murphy CA, Sandheinrich MB, Wiener JG (2012b) Toxicity of dietary methylmercury to fish: derivation of ecologically meaningful threshold concentrations. Environ Toxicol Chem 31:1536-1547

DeSorbo CR, Burgess NM, Nye PE, Loukmas JJ, Brant HA, Burton MEH, Persico CP, Evers DC (2020) Bald eagle mercury exposure varies with region and site elevation in New York, USA. https:// doi.org/10.1007/s10646-019-02153-8

Dittman JA, Shanley JB, Driscoll CT, Aiken GR, Chalmers AT, Towse JE, Selvendiran P (2010) Mercury dynamics in relation to dissolved organic carbon concentration and quality during high flow events in three northeastern U.S. streams. Water Resour Res 46:W07522. https://doi.org/10.1029/2009WR008351

Drevnick PE, Engstrom DR, Driscoll CT, Balogh SJ, Kamman NC, Long DT, Muir DGC, Parsons MJ, Rolfhus KR, Rossmann R, Swain EB (2012) Spatial and temporal patterns of mercury accumulation in lacustrine sediments across the Laurentian Great Lakes region. Environ Pollut 161:252-260

Driscoll CT, Yan C, Schofield CL, Munson R, Holsapple J (1994) The mercury cycle and fish in the Adirondack lakes. Environ Sci Technol 28:136A-143A

Driscoll CT, Han Y-J, Chen CY, Evers DC, Lambert KF, Holsen TM, Kamman NC, Munson RK (2007) Mercury contamination in forest and freshwater ecosystems in the Northeastern United States. BioScience 57:17-28

Driscoll CT, Chen CY, Hammerschmidt CH, Mason RP, Gilmour CC, Sunderland EM, Greenfield B, Lamborg CH (2012) Nutrient supply and mercury dynamics in marine ecosystems: a conceptual model. Environ Res 119:118-131

Driscoll CT, Mason RP, Chan HM, Jacob DJ, Pirrone N (2013) Mercury as a global pollutant: Sources, pathways and effects. Environ Sci Technol 47:4967-4983

Driscoll CT, Driscoll KM, Fakhraei H, Civerolo K (2016) Long-term temporal trends and spatial patterns in the acid-base chemistry of lakes in the Adirondack region of New York in response to decreases in acidic deposition. Atmos Environ 146:5-14. https:// doi.org/10.1016/j.atmosenv.2016.08.034

Dzielski SA, Razavi NR, Twining CW, Cleckner LB, Rohwer VG (2020) Reconstructing avian mercury concentrations through time using museum specimens from New York State. Ecotoxicology. https://doi.org/10.1007/s10646-019-02123-0

Eagles-Smith CA, Ackerman JT, De La Cruz SE, Takekawa JY (2009) Mercury bioaccumulation and risk to three waterbird foraging guilds is influenced by foraging ecology and breeding stage. Environ Pollut 157:1993-2002 
Eagles-Smith CA, Ackerman JT, Willacker JJ, Tate MT, Lutz MA, Fleck JA, Stewart AR, Wiener JG, Evers DC, Lepak JM, Davis JA, Pritz CF (2016) Spatial and temporal patterns of mercury concentrations in freshwater fish across the Western United States and Canada. Sci Total Environ 568:1171-1184

Edmonds ST, Evers DC, Cristol DA, Mettke-Hofmann C, Powell LL, McGann AJ, Armiger JW, Lane OP, Tessler DF, Newell P, Heyden K (2010) Geographic and seasonal variation in mercury exposure of the declining rusty blackbird. Condor 112:789-799

Evers DC (2018) The effects of methylmercury on wildlife: a comprehensive review and approach for interpretation. Encyclopedia Anthropocene 5:181-194

Evers DC, Clair TA (2005) Mercury in northeastern North America: a synthesis of existing databases. Ecotoxicology 14:7-14

Evers DC, Sunderland E (2019) Technical information report on mercury monitoring in biota. United Nations Environment Programme, Geneva, Switzerland

Evers DC, Burgess NM, Champoux L, Hoskins B, Major A, Goodale WM, Taylor RJ, Poppenga R, Daigle T (2005) Patterns and interpretation of mercury exposure in freshwater avian communities in northeastern North America. Ecotoxicology 14:193-221

Evers DC, Han YJ, Driscoll CT, Kamman NC, Goodale MW, Lambert KF, Holsen TM, Chen CY, Clair TA, Butler T (2007) Biological mercury hotspots in the northeastern United States and southeastern Canada. BioScience 57:29-43

Evers DC, Wiener JG, Basu N, Bodaly RA, Morrison HA, Williams KA (2011) Mercury in the Great Lakes region: bioaccumulation, spatiotemporal patterns, ecological risks, and policy. Ecotoxicology 20:1487-1499

Evers DC, Keane SE, Basu N, Buck D (2016) Evaluating the effectiveness of the Minamata Convention on Mercury: Principles and recommendations for next steps. Sci Total Environ 569570:888-903

Gerson JR, Driscoll CT, Demers J, Sauer A, Blackwell B, Monstesdeoca M, Shanley J, Ross D (2017) Deposition of mercury in forests across a montane elevation gradient: elevational and seasonal patterns in methylmercury inputs and production. J Geophys Res Biogeosciences 122:1922-1939

Giang A, Selin NE (2016) Benefits of mercury controls for the United States. Proc Natl Acad Sci USA 113:286-291. https://doi.org/10. 1073/pnas.1514395113

Gilmour CC, Henry EA (1991) Mercury methylation in aquatic systems affected by acid deposition. Environ Pollut 71:131-169

Gilmour CC, Podar M, Bullock AL, Graham AM, Brown SD, Somenahally AC, Johs A, Hurt RA, Bailey KL, Elias DA (2013a) Mercury methylation by novel microorganisms from new environments. Environ Sci Technol 47:11810-11820

Gilmour CC, Podar M, Bullock AL, Graham AM, Brown SD, Somenahally AC, Johs A, Hurt Jr RA, Bailey KL, Elias DA (2013b) Mercury methylation by novel microorganisms from new environments. Environ Sci Technol 47:11810-11820

Glass GE, Sorensen JA, Schmidt KW, Rapp Jr GR (1990) New source identification of mercury contamination in the Great Lakes. Environ Sci Technol 24:1059-1069

GLRC (Great Lakes Regional Collaboration) (2010) Great Lakes mercury emission reduction strategy. 30 June 2011. http://www. glrc.us/initiatives/toxics/index.html

Great Lakes Fish Advisory Workgroup (2007) A protocol for mercury based fish consumption advice: an addendum to the 1993 protocol for a uniform Great Lakes sport fish consumption advisory. Minnesota Department of Health, pp 30. https://www.health.state. mn.us/communities/environment/fish/docs/consortium/ mercuryprot.pdf

Goodrich B, GabryJ, Ali I, Brilleman S (2018) Bayesian applied regression modeling via Stan [WWW Document]. http://mc-stan.org
Grieb TM, Fisher NS, Karimi R, Levin L (2020) An assessment of temporal trends in mercury concentrations in fish. Ecotoxicology. https://doi.org/10.1007/s10646-019-02112-3

Gustin MS, Evers DC, Bank MS, Hammerschmidt CR, Pierce A, Basu N, Blum J, Bustamante P, Chen C, Driscoll CT, Horvat M, Jaffe D, Pacyna J, Pirrone N, Selin N (2016) Importance of integration and implementation of emerging and future mercury research into the Minamata Convention. Environ Sci Technol 50:2767-2770

Hintelmann H, Harris R, Heyes A, Hurley JP, Kelly CA, Krabbenhoft DP, Lindberg S, Rudd JW, Scott KJ, St. Louis VL (2002) Reactivity and mobility of new and old mercury deposition in a boreal forest ecosystem during the first year of the METAALICUS study. EnvironSci Technol 36:5034-5040

Hsu-Kim H, Kucharzyk KH, Zhang T, Deshusses MA (2013) Mechanisms regulating mercury bioavailability for methylating microorganisms in the aquatic environment: a critical review. Environ Sci Technol 47:2441-2456

Hsu-Kim H, Eckley CS, Achá D, Feng X, Gilmour CC, Jonsson S, Mitchell CP (2018) Challenges and opportunities for managing aquatic mercury pollution in altered landscapes. Ambio 47:141-169

Jackson AK, Evers DC, Etterson MA, Condon AM, Folsom SB, Detweiler J, Schmerfeld J, Cristol DA (2011) Mercury exposure affects the reproductive success of a free-living terrestrial songbird, the Carolina Wren (Thryothorus ludovicianus). Auk 128:759-769

Jackson AK, Evers DC, Adams EM, Cristol DA, Eagles-Smith C, Edmonds ST, Gray CE, Hoskins B, Lane OP, Sauer A, Tear T (2015) Songbirds as sentinels of mercury in terrestrial habitats of eastern North America. Ecotoxicology. 24:453-467

Jiskra M, Sonke JE, Obrist D, Bieser J, Ebinghaus R, Myhre CL, Pfaffhuber KA, Wängberg I, Kyllönen K, Worthy D, Martin LG (2018) A vegetation control on seasonal variations in global atmospheric mercury concentrations. Nat Geoscience 11:244-250

Karimi R, Fitzgerald TP, Fisher NS (2012) A quantitative synthesis of mercury in commercial seafood and implications for exposure in the United States. Environ Health Perspect 120:1512-1519

Karimi R, Frisk M, Fisher NS (2013) Contrasting food web factor and body size relationships with $\mathrm{Hg}$ and $\mathrm{Se}$ concentrations in marine biota. PloS ONE 8(9):e74695

Knightes CD, Sunderland EM, Barber MC, Johnson JM, Ambrose RB (2009) Application of ecosystem-scale fate and bioaccumulation models to predict fish mercury response times to changes in atmospheric deposition. Environ Toxicol Chemis 28:881-893

Kocman D, Wilson S, Amos H, Telmer K, Steenhuisen F, Sunderland E, Mason RP, Outridge P, Horvat M (2017) Toward an assessment of the global inventory of present day mercury releases to freshwater environments. Int J Environ Res Public Health 14:138. https://doi.org/10.3390/ijerph14020138

Lane OP, O'Brien KM, Evers DC, Hodgman TP, Major A, Pau N, Ducey MJ, Taylor R, Perry D (2011) Mercury in breeding saltmarsh sparrows (Ammodramus caudacutus caudacutus). Ecotoxicology 20:1984-1991

Lane O, Adams EM, Pau N, O’Brien KM, Regan R, Farina M, Schneider Moran T, Zarudsky J (2020) Long-term monitoring of mercury in adult saltmarsh sparrows breeding in Maine, Massachusetts and New York, USA 2000-2017. Ecotoxicology 29:1148-1160

Latifovic R, Pouliot D, Olthof I (2017) Circa 2010 land cover of Canada: local optimization methodology and product development. Remote Sens 9(11):1098

Lee CS, Lutcavage ME, Chandler E, Madigan DJ, Cerrato RM, Fisher NS (2016) Declining mercury concentrations in bluefin tuna reflect reduced emissions to the North Atlantic Ocean. Environ Sci Technol 50:12825-12830

Lin CJ, Shetty SK, Pan L, Pongprueksa P, Jang C, Chu HW (2012) Source attribution for mercury deposition in the contiguous 
United States: Regional difference and seasonal variation. J Air Waste Manag Assoc 62:52-63

Mahaffey KR, Clickner RP, Jeffries RA (2009) Adult women's blood mercury concentrations vary regionally in the United States: association with patterns of fish consumption (NHANES 1999-2004). Environ Health Perspect 117:47-53. https://doi.org/ 10.1289/ehp.11674.

Millard GD, Riva-Murray K, Burns DA, Montesdeoca MR, Driscoll CT (2020a) The impact of lime additions on mercury dynamics in stream chemistry and macroinvertebrates: a comparison of watershed and direct stream addition management strategies. Ecotoxicology. https://doi.org/10.1007/s10646-020-02224-1

Millard GD, Driscoll CT, Montesdeoca M, Yang Y, Taylor M, Boucher S, Shaw A, Richter W, Paul E, Parker C, Yokota K (2020b) Patterns and trends of fish mercury in New York State. Ecotoxicology. https://doi.org/10.1007/s10646-020-02163-x

Milford JA, Pienciak A (2009) After the clean air mercury rule: prospects for reducing mercury emissions from coal-fired power plants. Environ Sci Technol 43:2669-2673. https://doi.org/10. $1021 / \mathrm{es} 802649 \mathrm{u}$

NEI (National Emissions Inventory) for Hazardous Air Pollutants (2014) U.S. Environmental Protection Agency. https://www.epa. gov/airemissions-inventories/national-emissions-inventorynei

Nelson SJ, Chen CY, Kahl JS (2020) Dragonfly larvae as biosentinels of $\mathrm{Hg}$ bioaccumulation in Northeastern and Adirondack lakes: relationships to abiotic factors. Ecotoxicology. https://doi.org/10. 1007/s10646-019-02149-4

Obrist D, Kirk JL, Zhang L, Sunderland EM, Jiskra M, Selin NE (2018) A review of global environmental mercury processes in response to human and natural perturbations: changes of emissions, climate, and land use. Ambio 47:116-140

Olson CI, Fahraei H, Driscoll CT (2020) Mercury emissions, atmospheric concentrations, and wet deposition across conterminous United States: changes over 20 years of monitoring. Environ Sci Technol Lett 7:376-381

Perkins M, Lane OP, Evers DC, Sauer A, Adams EM, O’Driscoll NJ, Edmonds ST, Jackson AK, Hagelin JC, Trimble J, Sunderland EM (2020) Historical patterns in mercury exposure for North American songbirds. Ecotoxicology 29:1161-1173

Podar M, Gilmour CC, Brandt CC, Soren A, Brown SD, Crable BR, Palumbo AV, Somenahally AC, Elias DA (2015) Global prevalence and distribution of genes and microorganisms involved in mercury methylation. Sci Adv 1(9):e1500675. https://doi.org/10. 1126/sciadv.1500675

R Core Team (2018) R: a language and environment for statistical computing. R Foundation for Statistical Computing, Vienna, Austria. ISBN 3-9000-07-0 [WWW Document]. http://www.rproject.org/

Rallo M, Lopez-Anton MA, Contreras ML, Maroto-Valer MM (2012) Mercury policy and regulations for coal-fired power plants. Environ Sci Pollut Res 19:1084-1096

Razavi R, Halfman JD, Cushman SF, Massey T, Beutner R, Foust J, Gilman B, Cleckner L (2020) Mercury concentrations in fish and invertebrates of the Finger Lakes in central New York. Ecotoxicology. https://doi.org/10.1007/s10646-019-02132-z

Richter W, Skinner L (2020) Mercury in the fish of New York's Great Lakes: a quarter century of near stability. Ecotoxicology. https:// doi.org/10.1007/s10646-019-02130-1

Rimmer CC, McFarland KP, Evers DC, Miller EK, Aubry Y, Busby D, Taylor RJ (2005) Mercury concentrations in Bicknell's thrush and other insectivorous passerines in montane forests of northeastern North America. Ecotoxicology 14:223-240

Rimmer CC, Lloyd JD, McFarland KP, Evers DC, Lane OP (2020) Patterns of blood mercury variation in two long-distance migratory thrushes on Mount Mansfield, Vermont. Ecotoxicology 29:1174-1182
Riva-Murray K, Razavi R, Richter W, Cleckner L, Burns D (2020a) Mercury in fish from New York's streams and rivers: recent spatial patterns and long-term trends. Ecotoxicology. https://doi. org/10.1007/s10646-020-02225-0

Riva-Murray K, Bradley PM, Brigham ME (2020b) Methylmercurytotal mercury ratios in predator and primary consumer macroinvertebrates of Adirondack streams (New York, USA). Ecotoxicology. https://doi.org/10.1007/s10646-020-02191-7

Sauer AK, Driscoll CT, Evers DC, Adams EM, Yang Y (2020a) Mercury exposure in songbird communities in Sphagnum bog and upland forest ecosystems in the Adirondack Park (New York, USA). Ecotoxicology. https://doi.org/10.1007/s10646019-02142-x

Sauer AK, Driscoll CT, Evers DC, Adams EM, Yang Y (2020b) Mercury exposure in songbird communities along an elevational gradient on Whiteface Mountain, Adirondack Park (New York, USA). Ecotoxicology. https://doi.org/10.1007/s10646-020-02175-7

Scheuhammer A, Braune B, Chan HM, Frouin H, Krey A, Letcher R, Loseto L, Noël M, Ostertag S, Ross P, Wayland M (2015) Recent progress on our understanding of the biological effects of mercury in fish and wildlife in the Canadian Arctic. Sci Total Environ 509:91-103

Schmeltz D, Evers DC, Driscoll CT, Artz R, Cohen M, Gay D, Haeuber R, Krabbenhoft DP, Mason R, Morris K, Wiener JG (2011) MercNet: a national monitoring network to assess responses to changing mercury emissions in the United States. Ecotoxicology 20:1713-1725

Schoch N, Yang Y, Yanai R D, Buxton VL, Evers DC, Driscoll CT (2020) Spatial patterns and temporal trends in mercury concentrations in common loons (Gavia immer) from 1998 to 2016 in New York's Adirondack Park: has this top predator benefitted from mercury emission controls? Ecotoxicology. https://doi.org/ 10.1007/s10646-019-02119-w

Seewagen CL, Cristol DA, Gerson AR (2016) Mobilization of mercury from lean tissues during simulated migratory fasting in a model songbird. Sci Rep 6:25762

Selin NE (2011) Science and strategies to reduce mercury risks: a critical review. J Environ Monit 13:2389-2399. https://doi.org/ $10.1039 / \mathrm{c} 1 \mathrm{em} 10448 \mathrm{a}$

Stan Development Team (2018) Rstan: the R interface to Stan [WWW Document]. http://mc-stan.org

Streets DG, Horowitz HM, Jacob DJ, Lu Z, Levin L, Ter Schure AFH, Sunderland EM (2017) Total mercury released to the environment by human activities. Environ Sci Technol 51:5969-5977

Streets DG, Horowitz HM, Lu Z, Levin L, Thackray CP, Sunderland EM (2019) Global and regional trends in mercury emissions and concentrations, 2010-2015. Atmos Environ 201:417-427

Sunderland EM, Driscoll Jr CT, Hammitt JK, Grandjean P, Evans JS, Blum JD, Chen CY, Evers DC, Jaffe DA, Mason RP, Goho S, Jacobs W (2016) Benefits of regulating hazardous air pollutants from coal and oil-fired utilities in the United States. Environ Sci Technol 50:2117-2120

Sunderland EM, Li M, Bullard K (2018) Decadal changes in the edible supply of seafood and methylmercury exposure in the United States. Environ Health Perspect 126:017006

Swinton MW, Nierzwicki-Bauer SA (2020) Mercury increase in Lake Champlain fish: links to fishery dynamics and extreme climatic events. Ecotoxicology. https://doi.org/10.1007/ s10646-019-02148-5

Taylor MS, Driscoll CT, Lepak JM, Josephson DC, Jirka KJ, Kraft CE (2020) Temporal trends in fish mercury concentrations in an Adirondack Lake managed with a continual predator removal program. Ecotoxicology. https://doi.org/10.1007/s10646-019-02156-5

Todorova S, Driscoll CT, Effler SW, O'Donnell S, Matthews DA, Todorov DL, Gindlesperger S (2014) Changes in the long-term supply of mercury species to the upper mixed waters of a recovering lake. Environ Pollut 185:314-321 
UN Environment (2019) Global mercury assessment 2018. UN Environment Programme, Chemicals and Health Branch Geneva, Switzerland

U.S. EPA (Environmental Protection Agency) (1997) Great Lakes binational toxics strategy. https://archive.epa.gov/greatlakes/p2/w eb/pdf/bnssign.pdf

US Environmental Protection Agency (2020) National Emissions Inventory (NEI). Available at https://www.epa.gov/air-emissionsinventories/nationalemissions-inventory-nei

USEPA (Environmental Protection Agency) (2001) Water quality criterion for the protection of human health: methylmercury. EPA-823-R-01-001

United States Food and Drug Administration and United States Environmental Protection Agency (FDA/EPA) (2019) Technical Information on Development of FDA/EPA Advice about Eating Fish for Women Who Are or Might Become Pregnant, Breastfeeding Mothers, and Young Children. https://www.fda.gov/food/ metals-and-your-food/technical-information-development-fda epa-advice-about-eating-fish-women-who-are-or-might-become

Waller K, Driscoll C, Lynch J, Newcomb D, Roy K (2012) Long-term recovery of lakes in the Adirondack region of New York to decreases in acidic deposition. Atmos Environ 46:56-64

Warren DR, Kraft CE, Josephson DC, Driscoll CT (2016) Acid rain recovery may help to mitigate the impacts of climate change on thermally sensitive fish in lakes across eastern North America. Glob Change Biol 23(6):2149-2153. https://doi.org/10.1111/gcb. 13568

Wang F, Outridge PM, Feng X, Meng B, Heimbürger-Boavida LE, Mason RP (2019) How closely do mercury trends in fish and other aquatic wildlife track those in the atmosphere?-Implications for evaluating the effectiveness of the Minamata Convention. Sci Total Environ 674:58-70. https://doi.org/10.1016/j.scitotenv. 2019.04.101

Wang T, Driscoll CT, Hwang K, Chandler D, Montesdeoca M (2020) Seasonal patterns of total and methyl mercury concentrations in ground and surface waters in natural and restored freshwater wetlands in Northern New York. Ecotoxicology

Warren DR, Kraft CE, Josephson DC, Driscoll CT (2016) Acid rain recovery may help to mitigate the impacts of climate change on thermally sensitive fish in lakes across eastern North America. Glob Change Biol 23(6):2149-2153. https://doi.org/10.1111/gcb.13568

Watras CJ, Teng HY, Latzka AW, Meyer MW, Zhang Z (2020) Neardecadal oscillation of water levels and mercury bioaccumulation in the Laurentian Great Lakes region. Environ Sci Technol Lett 7:89-94
Willacker JJ, Eagles-Smith CA, Kowalski BM, Danehy RJ, Jackson AK, Adams EM, Evers DC, Eckley CS, Tate MT, Krabbenhoft DP (2019) Timber harvest alters mercury bioaccumulation and food web structure in headwater streams. Environ Pollut 253:636-645

Wyn B, Kidd KA, Burgess NM, Curry RA (2009) Mercury biomagnification in the food webs of acidic lakes in Kejimkujik National Park and National Historic Site, Nova Scotia. Can J Fisheries Aquat Sci 66:1532-1545

Yang L, Jin S, Danielson P, Homer C, Gass L, Case A, Costello C, Dewitz J, Fry J, Funk M, Grannemann B, Rigge M, Xian G (2018) A new generation of the United States National Land Cover Database: requirements, research priorities, design, and implementation strategies. ISPRS J Photogramm Remote Sens 146:108-123

Yang Y, Yanai RD, Schoch S, Buxton VL, Gonzalez K, Evers DC, Lampman G (2020) Determining optimal sampling strategies for monitoring mercury and reproductive success in common loons in the Adirondacks of New York. Ecotoxicology. https://doi.org/ 10.1007/s10646-019-02122-1

Ye Z, Mao H, Driscoll CT (2020) A modeling study on impacts of meteorological variation and anthropogenic emission reductions on atmospheric mercury input to upstate New York ecosystems. Ecotoxicology. https://doi.org/10.1007/s10646-019-02113-2

Ye Z, Mao H, Driscoll CT (2019) Primary effects of changes in meteorology vs. anthropogenic emissions on mercury wet deposition: a modeling study. Atmos Environ 198:215-225

Yu X, Driscoll CT, Montesdeoca M, Evers DC, Duron M, Williams K, Schoch N, Kamman NC (2011) Spatial patterns of mercury in biota of Adirondack, New York lakes. Ecotoxicology 20:1543-1554

Zhang Y, Jacob DJ, Horowitz HM, Chen L, Amos HM, Krabbenhoft DP, Slemr F, Louis VLS, Sunderland EM (2016) Observed decrease in atmospheric mercury explained by global decline in anthropogenic emissions. Proc Natl Acad Sci USA 113:526-531.

Zhou H, Zhou C, Lynam MM, Dvonch JT, Barres JA, Hopke PK, Cohen M, Holsen TM (2017) Atmospheric mercury temporal trends in the northeastern United States from 1992 to 2014: are measured concentrations responding to decreasing regional emissions? Environ Sci Technol Lett 4:91-97. https://doi.org/10. 1021/acs.estlett.6b00452

Zhou C, Cohen MD, Crimmins BA, Zhou H, Johnson TA, Hopke PK, Holsen TM (2017) Mercury temporal trends in top predator fish of the Laurentian Great Lakes from 2004 to 2015: are concentrations still decreasing? Environ Sci Technol 51:7386-7394 